University of Nebraska - Lincoln

DigitalCommons@University of Nebraska - Lincoln

Paleoceanography of the Gulf of Alaska During the Past 15,000 Years: Results From Diatoms, Silicoflagellates, and Geochemistry

John A. Barron

U.S. Geological Survey, MS910, Menlo Park, CA 94025, United States

David Bukry

U.S. Geological Survey, MS910, Menlo Park, CA 94025, United States

Walter E. Dean

U.S. Geological Survey, Denver, CO, dean@usgs.gov

Jason A. Addison

Alaska Quaternary Center and Department of Geology \& Geophysics, University of Alaska Fairbanks, PO Box 755870, Fairbanks, AK 99775, United States

Bruce Finney

Department of Biological Sciences, Idaho State University, Stop 8007, Pocatello, ID 83209, United States

Follow this and additional works at: https://digitalcommons.unl.edu/usgsstaffpub

Part of the Earth Sciences Commons

Barron, John A.; Bukry, David; Dean, Walter E.; Addison, Jason A.; and Finney, Bruce, "Paleoceanography of the Gulf of Alaska During the Past 15,000 Years: Results From Diatoms, Silicoflagellates, and Geochemistry" (2009). USGS Staff -- Published Research. 326.

https://digitalcommons.unl.edu/usgsstaffpub/326

This Article is brought to you for free and open access by the US Geological Survey at DigitalCommons@University of Nebraska - Lincoln. It has been accepted for inclusion in USGS Staff -- Published Research by an authorized administrator of DigitalCommons@University of Nebraska - Lincoln. 


\title{
Paleoceanography of the Gulf of Alaska during the past 15,000 years: Results from diatoms, silicoflagellates, and geochemistry
}

\author{
John A. Barron ${ }^{\text {a,* }}$, David Bukry ${ }^{\mathrm{a}}$, Walter E. Dean ${ }^{\mathrm{b}}$, Jason A. Addison ${ }^{\mathrm{c}}$, Bruce Finney ${ }^{\mathrm{d}}$ \\ a U.S. Geological Survey, MS910, Menlo Park, CA 94025, United States \\ b U.S. Geological Survey, Box 25046, MS980, Denver, CO 80225, United States \\ c Alaska Quaternary Center and Department of Geology E' Geophysics, University of Alaska Fairbanks, PO Box 755870, Fairbanks, AK 99775, United States \\ d Department of Biological Sciences, Idaho State University, Stop 8007, Pocatello, ID 83209, United States
}

\section{A R T I C L E I N F O}

\section{Article history:}

Received 16 January 2009

Received in revised form 27 April 2009

Accepted 28 April 2009

\section{Keywords:}

Holocene

Younger Dryas

Bølling-Alleröd

Gulf of Alaska

Upwelling

Diatoms

Silicoflagellates

Geochemistry

Sea ice

Productivity

\begin{abstract}
A B S T R A C T
High-resolution records of diatoms, silicoflagellates, and geochemistry covering the past 15,000 years were studied in three cores from the Gulf of Alaska (GOA). Core EW0408-85JC in an oceanic setting on the Kayak Slope displays a paleoceanographic record similar to that at several locations on the California margin during deglaciation. Biologic productivity as reconstructed using geochemical and microfossil proxies increased abruptly during the Bølling-Alleröd (Bø-Al) warm interval (14.7-12.9 cal ka), declined during the Younger Dryas (YD) cold interval (12.9 to $11.7 \mathrm{cal} \mathrm{kyr} \mathrm{BP)}$, and rose again during the earliest Holocene. At this site, the record after $\sim 11 \mathrm{cal}$ kyr BP is dominated by oceanic diatoms and silicoflagellates, with geochemical proxies displaying more subtle variation.

Cores EW0408-66JC in the Yakobi Sea Valley near Cross Sound and EW0408-11JC in the Gulf of Esquibel contain an expanded, composite record along the southeast Alaskan margin. Core 66JC contains a detailed record of the $\mathrm{B} \emptyset-\mathrm{Al}$ and YD. Diatoms and silicoflagellates indicate that coastal upwelling and biosiliceous productivity were strong during the Bø-Al but declined during the YD. Sea ice-related diatoms increased in abundance during the YD, indicating cooler, but less productive waters.

The glacial to biogenic marine sediment transition in core 11JC occurs at $1280 \mathrm{cmbsf}$ (centimeters below sea floor), probably representing rising sea level and deglaciation early in the Bø-Al. Freshwater and sea-ice related diatoms are common in the lower part of the core (Bø-Al and YD), but upwelling-related diatoms and silicoflagellates quickly increased in relative abundance up-core, dominating the record of the past 11,000 years. Low oxygen conditions in the bottom water as reconstructed using geochemical proxies ( $U$ and Mo concentration) were most intense between $\sim 6.5$ and $2.8 \mathrm{cal} \mathrm{kyr} \mathrm{BP}$, the beginning of which is coincident with increases in abundance of upwelling-related diatoms.

The records from these three cores jointly thus made it possible to reconstruct paleoclimatic and paleoceanographic conditions at high northern Pacific latitudes during the last $15 \mathrm{kyr}$.
\end{abstract}

Published by Elsevier B.V.

\section{Introduction}

\subsection{Setting}

Two current systems dominate the circulation of the GOA, the subarctic gyre in the ocean basin and the Alaska Coastal Current (ACC) on the continental shelf (Fig. 1). The southern boundary of the subarctic gyre is the West Wind Drift, which divides as it approaches the west coast of North America into the southward-flowing California Current and the northward-flowing Alaska Current. At the northern border of the GOA, the Alaska Current turns southwestward, forming

\footnotetext{
* Corresponding author.

E-mail addresses: jbarron@usgs.gov (J.A. Barron), dbukry@usgs.gov (D. Bukry),
} dean@usgs.gov (W.E. Dean), ftjaal@uaf.edu (J.A. Addison), finney@isu.edu (B. Finney). the beginning of the Alaskan Stream, the western boundary current of the eastern subarctic gyre (Stabeno et al., 2004).

The GOA shelf is dominated by the ACC, which is forced by alongshore winds and large freshwater runoff. Strong cyclonic winds characterize the fall through spring, and substantial runoff occurs, which increases in late spring and peaks in fall (Stabeno et al., 2004). Even though this shelf area has a predominantly downwelling regime, during summer winds relax and periods of upwelling occur, which result in increased salinity at depth. While strong seasonal cycles and interannual variability are dominant scales in atmospheric forcing and the oceanic response, there is also forcing on ENSO (El Niño Southern Oscillation) and decadal time scales. It is uncertain how to quantify the causes of this decadal change because of the possible interactions between the PDO (Pacific Decadal Oscillation) and ENSO. Stabeno et al. (2004) point out that El Niños of 1977, 1987, and 1998 all featured warmer, wetter winters in the northern GOA. 


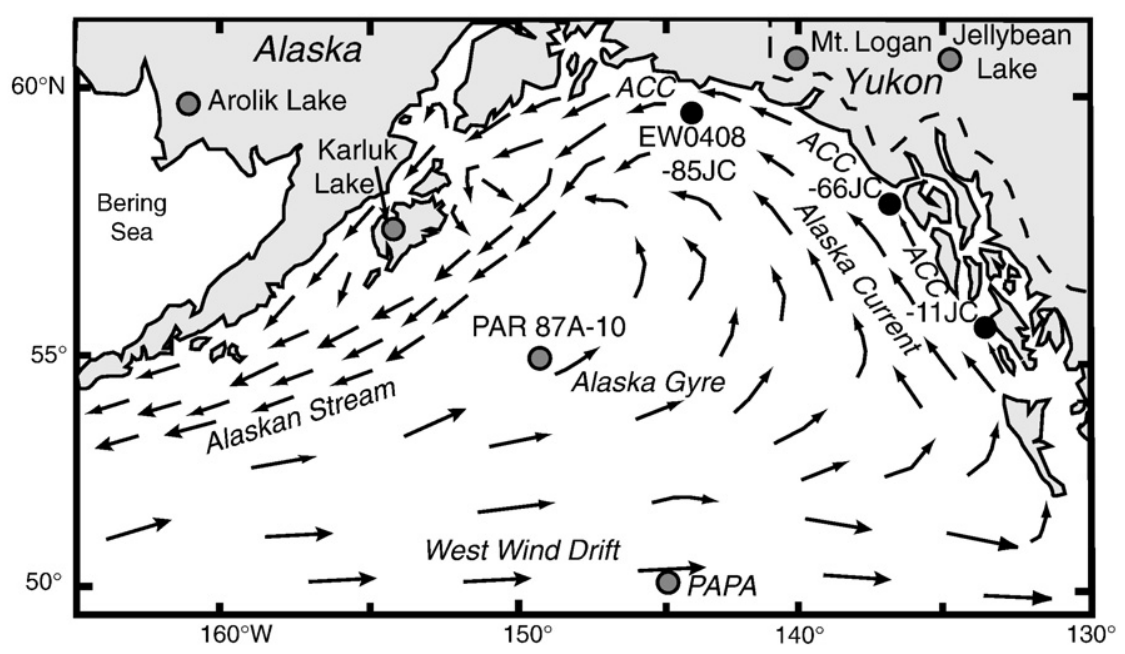

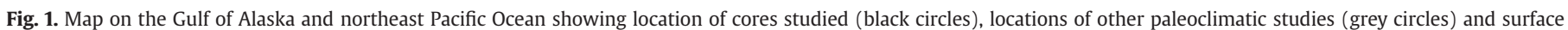
currents after Stabeno et al. (2004). ACC = Alaska Coastal Current.

A prominent wet period occurs from September through November, and a minor, relatively dry period characterizes June and July (Stabeno et al., 2004). Because precipitation falls in the form of snow during winter and rain in the summer, which melts the snow and ice in coastal watersheds, the coastal GOA experiences a stronger seasonal freshwater signal in runoff than in precipitation, with runoff maxima usually occurring in October (Royer, 2005).

During the winter, cooling of surface waters and winds associated with storms weaken stratification, and enhance vertical mixing, deepening the upper mixed layer, and entrain high concentrations of nutrients into surface waters (Childers et al., 2005). Deeper mixing of phytoplankton, decreased solar insolation, and persistent cloud cover all limit primary production in winter. From March to May, increased solar insolation and high nutrient concentrations lead to spring blooms of phytoplankton. In late spring and early summer (MayJune) intense algal blooms and low surface nutrients are observed across the shelf (Stabeno et al., 2004).

Mundy and Olsson (2005) argue that during positive phases of the PDO, a strong Aleutian Low results in strengthening of the ACC and an increase precipitation and runoff along the southeast Alaskan coast. During negative phases of PDO, on the other hand, a weak Aleutian Low results in a reduced ACC and reduced precipitation and surface runoff (Mundy and Olsson, 2005). Thus, it is expected that increased coastal upwelling and productivity along the southeast Alaskan margin will be associated with positive phases of the PDO (Mantua et al., 1997; Bond et al., 2003).

\subsection{Paleoceanography and paleoclimatology}

Relatively few detailed studies of Holocene paleoceanography and paleoclimatology have been completed in the GOA. DeVernal and Pedersen (1997) studied the dinocyst assemblages and biogenic fluxes in a 23,000 year-long record from core PAR87A-10 on the Patton Seamount within the central part of the Gulf of Alaska (Fig. 1). They concluded that the last glacial interval prior to $13 \mathrm{kyr} \mathrm{BP} \mathrm{(radiocarbon-}$ corrected age or about 14.7 cal kyr BP) was characterized by cold sea surface temperatures and freezing winter conditions. Increasing fluxes of microfossils indicating enhanced productivity characterized the glacial to interglacial transition until 8000-year BP radiocarboncorrected age (or about $\sim 9$ cal kyr BP), but salinities and sea-surface temperatures remained low compared to modern values. They argued that reduced biogenic fluxes in Holocene sediments younger than $\sim 9$ cal kyr BP suggested that eastward winds had become established over the North Pacific. DeVernal and Pedersen (1997) reconstructed sea surface temperatures (SST) using dinocyst assemblages suggest- ing that February and August SST rose steadily from about $\sim 14.7$ to $8.0 \mathrm{cal}$ kyr BP. They proposed that sea ice cover dropped from six to zero months per year between 14.7 and 10.0 cal kyr BP.

$\mathrm{Hu}$ et al. (2003) compiled a high-resolution record of biogenic silica (BSi) in sediments from Arolik Lake in southwestern Alaska (Fig. 1) for the period between $\sim 15.0$ and $2.0 \mathrm{cal}$ kyr BP. They argued that the lake's BSi record was strongly correlated to solar activity between $\sim 12.0$ and 2.0 cal $\mathrm{kyr} \mathrm{BP}$, with higher values of BSi corresponding to periods of increased solar activity and increased precipitation in southwestern Alaska.

Anderson et al. (2005) used oxygen isotopes in sediments from Jellybean Lake in the Yukon, Canada (Fig. 1), to infer the history of atmospheric circulation in the GOA during the past 7500 years. They pointed out that the $\delta^{18} \mathrm{O}$ of sedimentary calcite could be used to track moisture transport from the GOA across the coastal St. Elias Mountains. Their data suggested that between $\sim 7.5$ and $4.0 \mathrm{cal} \mathrm{kyr}$ $\mathrm{BP}$, the wintertime Aleutian Low (AL) pressure system was weaker and/or in a more westward position than at present. Between $\sim 4.5$ and $3.0 \mathrm{cal}$ kyr BP, the wintertime AL shifted eastward and intensified before shifting westward and weakening between $~ 3.0$ and $2.0 \mathrm{cal}$ kyr BP. Rapid shifts in the eastward position or intensification of the AL occurred between $\sim 1.2$ and 0.3 cal kyr BP, corresponding with glacial advances in the St. Elias Mountains and likely positive phases of the PDO.

Calkin et al. (2001) reviewed the Holocene coastal glaciation of Alaska, noting that whereas the earliest Holocene advance was of the Hubbard Glacier in Yakutat Bay at 6.85 cal kyr BP, many coastal glaciers expanded between $\sim 3.6$ and 3.0 cal kyr BP during the neoglacial period and during the Little Ice Age $\sim 1250$ to $1900 \mathrm{AD}$.

Finney et al. (2002) constructed a 2200-year-long record of sockeye salmon abundance from Karluk Lake and other lakes on Kodiak Island using $\delta^{15} \mathrm{~N}$. They noted that salmon abundance declined between $\sim 100$ BC and AD 800 when oligotrophic diatoms dominated in the lakes. Salmon abundance increased markedly during an interval rich in mesotrophic to eutrophic diatoms between AD 1200 and 1900. They observed that timing of Alaskan salmon abundance was opposite to that of anchovy abundance in the Santa Barbara Basin, supporting the hypothesis that conditions unlike those that dominated historical, 20th century records, or El Niño conditions, were predominant during the interval between $\sim A D 1200$ and 1900, which includes the Little Ice Age (LIA).

Fisher et al. (2008) documented a detailed ice core record recovered from Mt. Logan (5.4 km a.s.l.), in the southern Yukon that spans over 20,000 years. They argued that the $\delta^{18} \mathrm{O}$ of the ice is a proxy for source area of the moisture, with higher values being indicative of 
more northern sources and zonal atmospheric flow that is typical of La Niña's and lower values coinciding with a more southerly source like that of modern El Niño's. Fisher et al. (2008) suggested that low $\delta^{18} \mathrm{O}$ and enhanced meridional flow occurred between 8.0 and $7.0 \mathrm{cal} \mathrm{kyr}$ $\mathrm{BP}$ and at 4.2 cal kyr BP, which coincide with big changes in the Pacific palaeorecords of the balance between El Niño and La Niña. They argued that the time of $4.2 \mathrm{cal}$ kyr BP seems to have inaugurated the 'modern' ENSO world in the Pacific Northwest.

Addison et al. (2008; in prep.) present high-resolution evidence for paleoceanographic changes along the Gulf of Alaska margin over the last 10,000 years from the coastal fjords of Alaska. Using a detailed isotopic and biogeochemical approach, they show a clear transition towards a more productive marine ecosystem occurring at $\sim 4.0 \mathrm{cal} \mathrm{kyr}$ BP. They contend this transition corresponds to the onset of modern environmental cyclicity (e.g. changes in the linked Aleutian Low/ Alaska Gyre system) along the Subarctic Northeast Pacific Ocean margin, and that these changes also correspond to other contemporaneous terrestrial records of paleoenvironmental changes. Furthermore, the extremely high sedimentation rates present in these fjords $(0.1-0.5 \mathrm{~cm} / \mathrm{yr})$ provide the first-ever marine evidence of Holocene high-frequency subdecadal shifts from the subarctic northeast Pacific Ocean margin.

R/V Maurice Ewing Cruise EW0408 from August 21 to September 23, 2004 along the fjords and continental margin of southern Alaska collected gravity and jumbo piston cores from 37 sites for paleoclimatic and paleoceanographic study (http://www.marine-geo.org/ tools/search/entry.php?id=EW0408). Preliminary study of these cores by Bruce Finney (Idaho State University), Jason Addison (University of Alaska, Fairbanks), John Jaeger (University of Florida), Alan Mix, Nick Pisias, Fredrick Prahl and Joseph Stoner (Oregon State University), Ross Powell (Northern Illinois University), Sean Gulick (University of Texas), Larry Mayer (University of New Hamshire), Ellen Cowan (Appalachian State University) and Tom Ager (U.S. Geological Survey) has revealed that many of them contain detailed records of the past 15,000 years suitable for paleoceanographic study. The purpose of this report is to compare the detailed paleoceanographic history of various parts of the Alaskan margin using material from these cores.

\section{Materials and methods}

Three jumbo piston cores were studied for this report. Core EW0408-85JC was taken on the Kayak slope $\left(59^{\circ} 33.3235^{\prime} \mathrm{N}\right.$, $144^{\circ} 9.2092^{\prime} \mathrm{W}, 682 \mathrm{~m}$ water depth) and has a length of $1124 \mathrm{~cm}$. Core EW0408-66JC was collected in Yabobi Sea Valley near Cross Sound ( $57^{\circ} 52.3429^{\prime} \mathrm{N}, 137^{\circ} 6.2676^{\prime} \mathrm{W}, 426 \mathrm{~m}$ water depth) and has a core length of $1386 \mathrm{~cm}$, Core EW0408-11JC from the Gulf of Esquibel $\left(55^{\circ} 37.6007^{\prime} \mathrm{N}, 133^{\circ} 30.6897^{\prime} \mathrm{W}, 183 \mathrm{~m}\right.$ water depth) has a total length of $1752 \mathrm{~cm}$. These cores were selected because preliminary studies and age data suggested that they contained a detailed record of the past 15,000 years, and reconnaissance studies of the diatom assemblages indicated good preservation and strong variability.

Tom Ager collected samples at the Oregon State core repository at 10 to $20 \mathrm{~cm}$ intervals, corresponding to age intervals averaging from about 40 years $(66 \mathrm{JC})$ to 200 years (11JC and 85JC).

\subsection{Diatoms}

Strew slides for diatoms and silicoflagellates were prepared by placing about $0.2 \mathrm{~cm}^{3}$ of sediment in a glass vial and covering it with 710 times as much distilled water as sample. A disposable wooden stick was then used to disaggregate the samples in the vials by stirring the suspension. To prepare slides, the vial was shaken and a drop of the suspension was taken after $5-10 \mathrm{~s}$ of settling from near the top of the vial, transferred to a $40 \times 22 \mathrm{~mm}$ cover slip and dried at low heat on a hot plate. Slides were then mounted in Naphrax (index of diffraction $=1.74$ ).
At least 300 individual diatoms were identified and counted using the counting techniques of Schrader and Gersonde (1978) by making random traverses of the slide under the light microscope at 1250×. Following Sancetta (1992) and Barron et al. (2003), Chaetoceros resting spores were not counted in this qualitative study, as these are resistant to dissolution and their contribution can be enhanced by downslope transport. Nevertheless, quantitative studies of Chaetoceros spores such as that of Lopes et al. (2006) have proven to be useful in determining paleoproductivity patterns. Diatom abundances were estimated by recording the number of diatom valves encountered while making vertical traverses of the slide (length of traverse $=22 \mathrm{~mm}$ ) at $790 \times$. Random traverses were made until $>300$ diatom valves were counted.

\subsection{Silicoflagellates}

Silicoflagellates are diluted by diatoms and by coarse quartz silt. One to four slides were systematically tracked to obtain a representative count of 50 to 100 specimens per sample. Counts typically were made at $250 \times$ magnification, with $500 \times$ used for checking questionable specimens. All whole specimens and half specimens with intact apical structures were counted. Taxonomy follows that used by Bukry (1973, 1980,1981 ) for stratigraphic studies in the area. Intraspecific variants of silicoflagellate taxa were tabulated in an effort to determine paleoecologic preferences.

\subsection{Geochemistry}

Concentrations of total carbon (TC) and total inorganic carbon (TIC) were determined by coulometric titration of $\mathrm{CO}_{2}$ following extraction from the sediment by combustion at $950^{\circ} \mathrm{C}$ and acid volatilization, respectively (Engleman et al., 1985), in USGS Denver laboratories. Weight percent TIC was converted to weight percent $\mathrm{CaCO}_{3}$ by dividing by 0.12 , the fraction of carbon in $\mathrm{CaCO}_{3}$. Total organic carbon (TOC) was determined as the difference between TC and TIC. The accuracy and precision for both TC and TIC, determined from hundreds of replicate standards (reagent-grade $\mathrm{CaCO}_{3}$ and a Cretaceous OC-rich marlstone), usually are better than 0.10 wt.\%.

Samples were analyzed for 40 major, minor, and trace elements by inductively coupled plasma-mass spectrometry (ICP-MS) by SGS Laboratories, Toronto, Canada. Rock standards (USGS) were included with the sediment samples, and $5 \%$ of the samples were analyzed in duplicate. The precision, determined by analyzing rock standards and duplicate sediment samples, is better than $10 \%$, and usually better than $5 \%$ at a concentration of 10 times the limit of detection.

\section{Results}

\subsection{Geochronology}

Table 1 presents the AMS ${ }^{14} \mathrm{C}$ ages for cores $85 \mathrm{JC}, 66 \mathrm{JC}$, and 11JC and their calendar corrected ages according to the CALIB 5.01 software of Stuiver and Reimer (1993), using the INTCAL04 calibration curve of Reimer et al. (2004) assuming a marine carbonate reservoir effect of 732 years, based on the mean ${ }^{14} \mathrm{C}$ date discrepancy between paired marine bivalve and terrestrial wood samples from three different EW0408 cores. Terrestrial-derived wood fragments, spruce needles, and other non-aquatic organic materials were preferentially selected for AMS radiocarbon dating where available following sieving with a $250-\mu \mathrm{m}$-screen of 2-cm-thick bulk sediment samples. All ages are reported as the 2-sigma median probability age with uncertainties of one-half of the 2-sigma calibrated age range. Age vs. depth plots for these three cores is displayed on Fig. 2. Additional radiocarbon dating is in progress to help develop more detailed chronologies for these cores. 
Table 1

Radiocarbon dates, reservoir corrections, and calendar ages.

\begin{tabular}{lllllllr}
\hline $\begin{array}{l}\text { EW0408 } \\
\text { core }\end{array}$ & $\begin{array}{l}\text { Depth } \\
\text { (cmbsf) }\end{array}$ & Material & ${ }^{13} \mathrm{C}$ & $\begin{array}{l}{ }^{14} \mathrm{C} \\
\text { age }\end{array}$ & $\begin{array}{l}{ }^{14} \mathrm{C} \text { age } \\
\text { (reservoir } \\
\text { correction) }\end{array}$ & $\begin{array}{l}\text { 2 sigma range } \\
\text { calendar yr BP }\end{array}$ \\
\hline 11JC & 162 & Organics & & 2640 & 2640 & 35 & $2722-2844$ \\
& 278 & Wood & -25 & 2690 & 2690 & 40 & $2747-2861$ \\
& 415 & Organics & & 4815 & 4815 & 25 & $5477-5601$ \\
& 639 & Organics & & 7350 & 7350 & 70 & $8016-8329$ \\
& 742 & Wood & -25 & 8306 & 8306 & 47 & $9136-9442$ \\
& 820 & Organics & & 9110 & 9110 & 70 & $10,176-10,492$ \\
& 952 & Organics & & 9615 & 9615 & 35 & $10,780-11,167$ \\
& 1020 & Wood & -25 & 9707 & 9707 & 49 & $10,809-11,234$ \\
& 1097 & Plant material & -25 & 9733 & 9733 & 49 & $10,878-11,244$ \\
& 1178 & Wood & -25 & 9812 & 9812 & 62 & $11,109-11,390$ \\
& 1185 & Shell & 0 & 10,597 & 9865 & 54 & $11,184-11,590$ \\
66JC & 1295 & Tephra & & & & & $14,266-14,952$ \\
& 250 & Scaphopod & -4 & 11,110 & 10,325 & 40 & $12,062-12,564$ \\
& & (shell) & & & & & \\
85JC & 433 & Shell & -4 & 11,255 & 10,470 & 40 & $12,384-12,700$ \\
& 636 & Shell & 0 & 11,200 & 10,415 & 30 & $11,983-12,353$ \\
& 710 & Shell & -3 & 14,750 & 13,965 & 50 & $16,144-16,891$ \\
& 1022 & Shell & -3 & 15,475 & 14,690 & 50 & $17,150-17,942$ \\
\end{tabular}

AMS ${ }^{14} \mathrm{C}$ ages on EW0408 core material studied for this report.

\subsubsection{EW0408-85JC}

Core EW0408-85JC is composed of four major lithologic units. The uppermost unit, a dark gray silty clay [Unit 1] that extends from 0 to 610 cmbsf, conformably overlies a coarser gray silty clay with dispersed sand grains [Unit 2] from 610 to 645 cmbsf. A highly organic, gray silty clay with olive brown laminations [Unit 3] extends from 645 to $680 \mathrm{cmbsf}$, which in turn grades into a dark gray massive diamicton with scattered pebbles and large angular clasts [Unit 4] that continues to the bottom of 85JC at 1124 cmbsf.
Three bivalve macrofossils were analyzed by AMS ${ }^{14} \mathrm{C}$ techniques from core 85JC (Table 1). The youngest bivalve dates to $12,168 \pm 185$ cal yrs BP from Unit 2, while the remaining two samples from Unit 4 range between 16,500 and 17,600 cal yrs BP. The limited chronology available for 85JC suggests Unit 2 is contemporaneous with the Younger Dryas, and Unit 4 may be representative of LGI glacimarine deposition along the Northeast Pacific Ocean margin. Unit 1 most likely represents Holocene pelagic deposition; however with no age control associated with Unit 1, it is impossible to determine the temporal completeness of this unit at this time.

While Unit 3 itself contains no dated macrofossils, it is constrained by dates both above and below, which implies this laminated unit may be related to the Bølling-Alleröd. Geochemical proxies of paleoproductivity (e.g. Cd, Mo, and S) indicate enhanced primary productivity associated with Unit 3; similar productivity maxima are observed at the same time at other sites along the Pacific margin.

Applying a highly preliminary age model to the bivalve dates and lithologic changes suggests the Holocene section [Unit 1] of 85JC accumulated material at a rate of $51 \mathrm{~cm} / \mathrm{kyr}$. Geochemical proxies of paleoproductivity and associated lower oxygen in bottom waters $(\mathrm{Cd}$, Mo, U, and S) suggest that the YD should lie between $~ 645$ and $610 \mathrm{cmbsf}$ and that the lower boundary of the Bø-Al should be at $650 \mathrm{cmbsf}$, the base of the laminated sediments of Unit 3. The ages for the Younger Dryas ( $12.9 \mathrm{cal}$ kyr BP to $11.7 \mathrm{cal}$ kyr BP) and the base of Bølling-Alleröd (14.7 kyr BP) used in this report are after Steffensen et al.'s (2008) recent high-resolution dating of these events in the NGRIP ice core in Greenland. Placing the top of the YD at $610 \mathrm{cmbsf}$ implies an average sedimentation rate of $\sim 52 \mathrm{~cm} / \mathrm{kyr}$ for the Holocene. A sedimentation rate of $\sim 28 \mathrm{~cm} / \mathrm{kyr}$ for the $\mathrm{YD}, \mathrm{B} \emptyset-\mathrm{Al}$, and latest part of the LGI is estimated by the AMS dates and the geochemical constraints (Fig. 2).

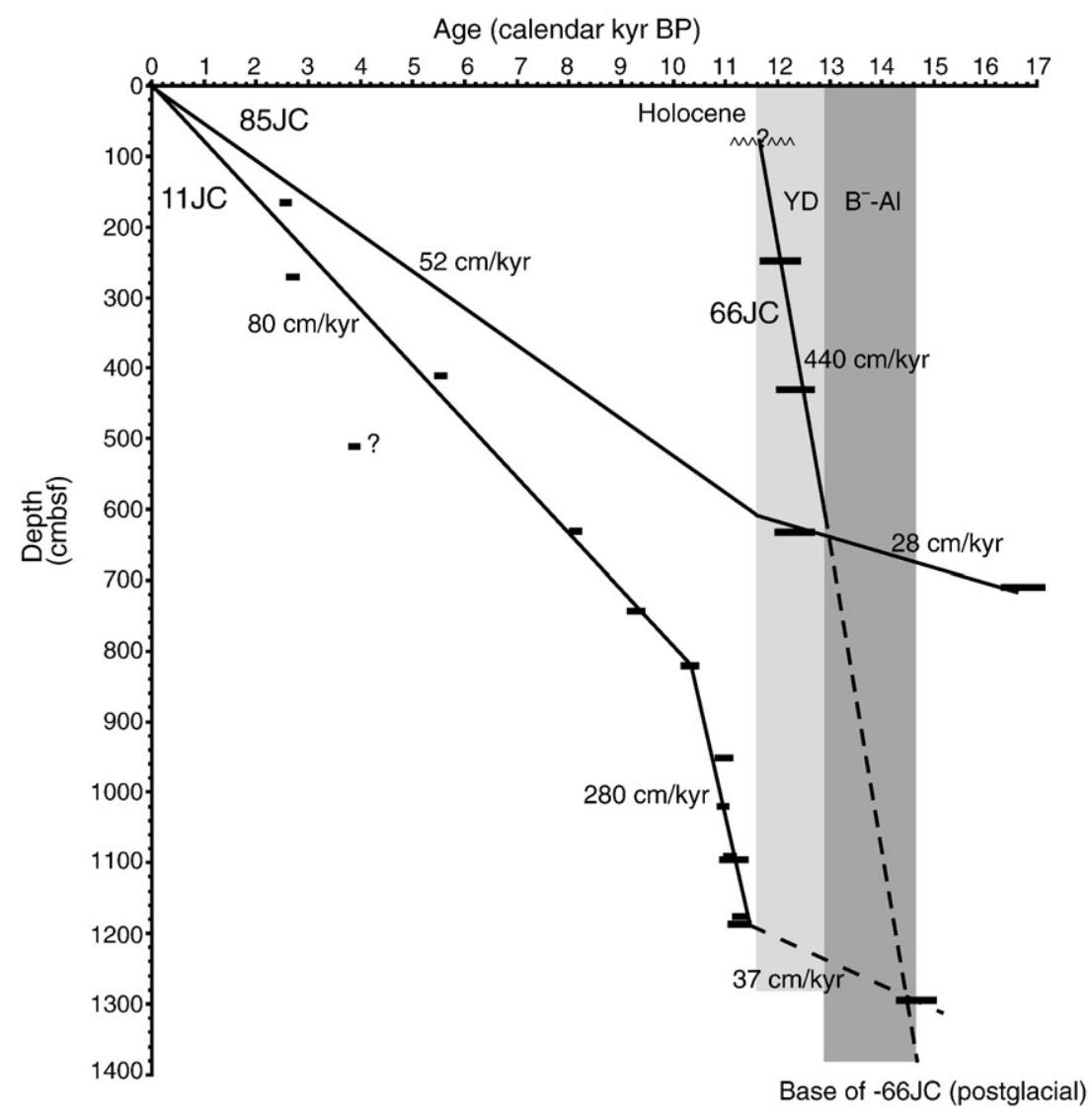

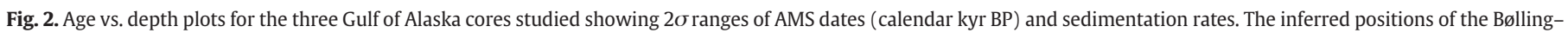
Alleröd (Bø-Al) warm interval and the Younger Dryas (YD) cold interval are shown (see text). $\mathrm{cmbsf}=\mathrm{cm}$ below sea floor. Data in Table 1 . 


\subsubsection{EW0408-66JC}

Core EW0408-66JC is constrained by two AMS ${ }^{14} \mathrm{C}$ dated horizons, a scaphopod tuskshell at $250 \mathrm{cmbsf}$ dated at $12,313 \pm 251$ cal yrs BP and a bivalve shell at $433 \mathrm{~cm}$ bsf dated at 12,542 \pm 158 cal yrs BP (Table 1) using a reservoir correction of 732 years. Both dates are associated with a dark greenish gray, organic-poor silty clay lithofacies from 53 to $572 \mathrm{cmbsf}$ that is overlain by a dark olive-gray, organic-rich silty clay horizon from 0 to $51 \mathrm{cmbsf}$. The upper horizon most likely represents Holocene autochtonous biogenic sediment; however, it may either correspond to a compressed or an erosionally-truncated section. The contact between the two units is marked by a distinctive 2-cm-thick crushed shell hash horizon that is indicative of a highenergy depositional event, suggesting the latter scenario as most likely. From 572 to $1380 \mathrm{cmbsf}$, a mottled dark-to-very-dark gray silty clay occurs with occasional sand laminations. Sediments recovered near the base of the core at $1362 \mathrm{cmbsf}$ contain abundant marine diatoms and appear to postdate the base of the Bølling-Alleröd (14.7 cal ka). A sedimentation rate of at least $440 \mathrm{~cm} / \mathrm{kyr}$ is thus implied for the lower (51-1380 cmbsf) organic-poor unit.

\subsubsection{EW0408-11JC}

The piston core EW0408-11JC recovered from the Gulf of Esquibel is composed of three major lithologic units. The uppermost Unit 1 is an olive-gray silty clay marked with faint laminations that extends from 0 to $1230 \mathrm{cmbsf}$, and conformably overlies a massive dark gray silty clay (Unit 2) with moderate bioturbation from 1230 to $1314 \mathrm{cmbsf}$. Within this massive silty clay at 1295-1298 cmbsf, a black tephra bed with a graded top contact and sharp bottom contact is present. Below $1314 \mathrm{cmbsf}$ is a conformable contact with a color interstratified (reddish-brown/light gray/dark gray) silty clay containing occasional dropstones (Unit 3) that extends to the bottom of core EW0408-11JC at $1762 \mathrm{cmbsf}$.

The chronology for EW0408-11JC was established using a complementary approach incorporating accelerator mass spectrometry (AMS) radiocarbon dating of macrofossils, and a volcanic tephra correlation to an adjacent lake sediment core from nearby Heceta Island (Tom Ager, written communication, 2008).

AMS ${ }^{14} \mathrm{C}$ dating was performed on 13 macrofossil samples recovered from EW0408-11JC, two of which were complete (e.g. non-fragmented) bivalve shells (Table 1). A wood fragment at 513 cmbsf exhibited an age anomalously young and was excluded from the chronology dataset due to the suggested stratigraphic leak implied by the date, perhaps due to contamination by modern ${ }^{14} \mathrm{C}$, or the sample was artificially emplaced at a deeper depth as a coring artifact.

Electron probe microanalysis of individual glass shards from the tephra at 1295 to $1298 \mathrm{cmbsf}$ correlate geochemically with a similar tephra discovered in a lake core taken from Leech Lake on Hecate Island, $15 \mathrm{~km}$ northwest of EW0408-11JC (Addison et al., 2006). The Leech Lake sediment core has a developed chronology with an AMS ${ }^{14} \mathrm{C}$ dated pollen residue of $14,609 \pm 343$ cal yrs BP directly overlying the tephra (Tom Ager, written communication). Using the Leech Lake age model, the age for the correlative EW0408-11JC tephra is thus constrained; however, considering the errors implied with this approach, this date should be considered a first-order approximation.

A provisional age-depth model for EW0408-11JC combines three separate linear plots constrained by the AMS dates: sedimentation rates of $\sim 37 \mathrm{cmbsf}$ between 1185 and $1296 \mathrm{cmbsf}$ ( 11.6 to $14.6 \mathrm{cal} \mathrm{kyr}$ BP), of $\sim 280 \mathrm{cmbsf}$ between 820 and $1185 \mathrm{cmbsf}$ ( 10.3 to $11.6 \mathrm{cal} \mathrm{kyr}$ $\mathrm{BP})$, and of $\sim 80 \mathrm{~cm} / \mathrm{kyr}$ between 0 and $820 \mathrm{cmbsf}(\sim 0$ to $10.3 \mathrm{cal} \mathrm{kyr}$ BP) (Fig. 2). These three intervals of differing sedimentation rate likely coincide with initial shallow marine sedimentation during the $\mathrm{B} ø-\mathrm{Al}$ and YD, followed by very fast sedimentation due to rapidly deepening marine conditions during the early Holocene, and finally more stabilized marine sedimentation after $\sim 10.3 \mathrm{cal}$ kyr BP. It is likely that the transitions between these different sedimentation rates did not occur so abruptly as depicted on Fig. 2, and additional dating that is currently underway will hopefully clarify this, as well as Holocene uncertainty.

\subsection{Diatom proxies}

The formal citations of the diatom taxa tabulated in the three cores are listed in the Appendix A along with notes about possible synonyms. The diatoms can be divided into differing ecological groups as discussed below.

\subsubsection{Sea ice and sea ice related diatoms}

Fragilariopsis oceanica (=Nitzschia grunowii) and Fragilariopsis cylindrus are considered as definite proxies for sea ice (Horner and Alexander, 1972; Sancetta, 1981).

Diatoms associated with sea ice, either in ice marginal waters or with the bloom that immediately follows the break-up of sea ice include Bacteriosira fragilis, Porosira glacialis, Thalassiosira gravida and its resting spores, T. hyalina, and T. nordenskioeldii. T. gravida and resting spores of $T$. antarctica cannot be distinguished according to Sancetta and Robinson (1983). Hasle and Heimdal (1968) report that T. antarctica is restricted to coastal or ice-margin waters, in conditions of low temperature $\left(-1\right.$ to $\left.4^{\circ} \mathrm{C}\right)$ and salinity (25-34\%). The abundance of $T$. gravida is indicative of cold water associated with ice in the Bering Sea (Baldauf, 1982) and it exhibits a positive correlation with sea-ice concentration in the Sea of Okhotsk (Shiga and Koizumi, 2000).

Areas under the influence of newly melted ice in the southeastern Bering Sea had dense populations of T. hyalina, T. nordenskioeldii and Fragilariopsis (Schandelmeier and Alexander, 1981).

Subpolar North Atlantic-Factor 5 of Andersen et al. (2004) is the sea-ice assemblage consisting primarily of $N$. grunowii ( $=F$. oceanica). Other important species in this assemblage are Nitzschia cylindra (=F. cylindrus), Thalassiosira hyalina, T. gravida spores, Thalassiosira nordenskioeldii and Bacterosira fragilis. The spatial distribution of this assemblage mirrors the limit of the sea-ice edge in winter (Andersen et al., 2004).

P. glacialis is often observed in association with sea ice (Grant and Horner 1976; von Quillfeldt, 1996).

\subsubsection{Temperate oceanic}

Thalassionema nitzschioides, Thalassiosira eccentrica, T. oestrupii, Azpeitia tabularis, Fragilariopsis doliolus, and Nitzschia sp. cf. N. bicapitata are tabulated as temperate oceanic taxa, meaning that they are open ocean diatoms that are common in subtropical to temperate waters of the North Pacific (Sancetta and Silvestri, 1986; Sancetta, 1992; Lopes et al., 2006).

\subsubsection{North Pacific}

Neodenticula seminae is associated with cold subarctic waters of the North Pacific (Sancetta and Silvestri, 1986; Takahashi, 1997). According to the sediment trap studies of Takahashi (1997), N. seminae is the dominant productivity factor in the south central Gulf of Alaska (Station PAPA, Fig. 1), which is typified by moderate sea surface temperature (SST) $\left(6-7{ }^{\circ} \mathrm{C}\right)$ and relatively high salinity (>33\%) (Sancetta, 1982).

\subsubsection{Sea of Okhotsk}

Sancetta and Silvestri (1986) consider Thalassiosira trifulta and Actinocyclus curvatulus to be indicative of cold, low-salinity surface water found in the Sea of Okhotsk in the spring after melting of the winter sea ice.

\subsubsection{Upwelling Thalassiosira}

Thalassiosira pacifica and small $(<10 \mu \mathrm{m}$ in diameter) Thalassiosira are tabulated as coastal upwelling indicators after Sancetta (1982), McQuoid and Hobson (2001), Katsuki and Takahashi (2005), Lopes et al. (2006), and Hay et al. (2007). 


\subsubsection{Shallow marine}

Transported diatoms include tychopelagic forms associated with the shelf (Actinoptychus spp., Paralia sulcata, Stephanopyxis spp.), benthic diatoms, and reworked fossil diatoms. The presence of these diatoms in the assemblages at the core sites is due to transport from shallower shelf areas.

\subsubsection{Freshwater diatoms}

Freshwater benthic diatoms and freshwater planktic diatoms (Aulacoseira spp., and Stephanodiscus spp. are included in this category.

\subsection{Silicoflagellate proxies}

The formal citations of the silicoflagellate taxa tabulated in the three cores are listed in the Appendix A along with notes about possible synonyms. The silicoflagellates can be divided into ecological groups as discussed below.

\subsubsection{Warm water and/or deep thermocline silicoflagellates}

Dictyocha aculeata is a silicoflagellate that ranges from the tropics to the Gulf of Alaska in the eastern North Pacific (Poelchau, 1976). D. aculeata likely reflects a deeper thermocline, in contrast to the Distephanus speculum group, which appears to be a proxy for shallow thermocline conditions associated with coastal upwelling (Barron and Bukry, 2007).

The normal small to medium form of Dictyocha stapedia is associated with oligotrophic nutrient-depleted conditions (Poelchau, 1976; Takahashi et al., 1989; Barron et al., 2005). Onodera and Takahashi (2005) consider D. stapedia (their D. messanenesis) to be a subtropical species, noting that its relative abundance closely follows increases in SST occurring during the summer at sediment trap Station $40 \mathrm{~N}\left(40^{\circ} 00^{\prime} \mathrm{N}, 165^{\circ} 00^{\prime} \mathrm{E}\right.$, water depth $\left.5,476 \mathrm{~m}\right)$ in the northwestern Pacific.

\subsubsection{Upwelling silicoflagellates}

The $D$. speculum group is an indicator of cooler, nutrient-rich waters that occur in regions of coastal upwelling (Poelchau, 1976; Takahashi et al., 1989). Distephanus speculum minutus increases its relative numbers poleward compared to populations of $D$. speculum $\mathrm{s}$. s. (Bukry, 1976, 1981, 1986, 1987). Studies of Holocene silicoflagellate populations in the eastern North Pacific (Bukry, unpublished data) confirm that $D$. speculum minutus is restricted to cooler waters north of Pt. Conception $\left(34^{\circ} \mathrm{N}\right)$ with its relative abundance increasing northward to piston core EW0408-07JC from offshore waters of Cordova Bay, Alaska $\left(\sim 55^{\circ} \mathrm{N}\right)$. Thus, increased $\%$ D. speculum minutus in ODP 1019 and EW9504-17PC is inferred to reflect cooling of surface waters.

\subsubsection{Subarctic silicoflagellates}

Distephanus octangulatus is a subarctic silicoflagellate that is most common in cooler waters of the North Pacific including the Bering Sea and Alaskan Gyre (Ling, 1973; Poelchau, 1976; Takahashi, 1997).

\subsection{Trace element proxies}

Aluminum ( $\mathrm{Al}$ ) and titanium ( $\mathrm{Ti}$ ) commonly are used as measures of terrigenous detrital input because their concentrations are largely unaffected by weathering and post-depositional alteration. Certain trace elements in marine sediments, such as cobalt (Co), gallium (Ga), cerium (Ce), lanthanum ( $\mathrm{La})$, lithium (Li), rubidium ( $\mathrm{Rb}$ ), thorium (Th), and yttrium (Y), also are derived almost entirely from terrigenous aluminosilicate sources (e.g., Brumsack, 1986; Piper and Dean, 2002). However, many trace elements, such as rhenium (Re), uranium (U), vanadium (V), nickel (Ni) cadmium (Cd), and molybdenum (Mo), are concentrated in organic carbon-rich sedi- ments where sulfate reduction has occurred (e.g., Jacobs et al., 1985; Emerson and Huested, 1991; Crusius et al., 1996). These elements may have two sources: (1) a biogenic source represented by trace elements taken up mostly in the photic zone by phytoplankton, and (2) a hydrogenous fraction derived from bottom water and (or) sediment pore water by hydrogenous adsorption and precipitation reactions. Elevated concentrations of one or more of these elements, along with sulfur, in sediments should indicate the extent of sulfate reduction in the past. We focus on Mo in this study because of the elements for which we have data; it is the diagnostic element in sediments that accumulated under seawater sulfate-reducing conditions (Bruland, 1983; Jacobs et al., 1985; Emerson and Huested, 1991; Piper, 1994; Crusius et al., 1996, Piper and Dean, 2002).

Piper and Dean (2002) calculated that $86 \%$ of the Cd mass accumulation rate (MAR) in Cariaco Basin sediments was biogenic, whereas $97 \%$ of the Mo MAR was hydrogenous formed by bottom water and (or) sediment pore-water reactions. Dean et al. (2006) concluded that the accumulation rate of $\mathrm{Cd}$, together with the accumulation rate of organic carbon, could be used as a measure of paleoproductivity on the Pacific margin of Baja California. The accumulation rate of Mo, on the other hand, together with the presence of laminated sediments could be used as a measure of oxygen depleted bottom waters, and that the depletion of dissolved oxygen (DO) was likely the result of decomposition of produced organic matter and not reduced ventilation. Zheng et al. (2000) found that thin intervals of laminated sediments deposited during the global $\mathrm{B} ø-\mathrm{Al}$ warm interval in two cores from the central California margin contained elevated concentrations of $\mathrm{Mo}$ and $\mathrm{Cd}$, similar to the situation in core 85JC. Therefore, we will use the concentration of $\mathrm{Cd}$ as a proxy for paleoproductivity, and the concentration of Mo, together with that of $S$ and the presence of laminated sediments, can be used as a measure of DO deficiency and sulfate reduction.

\section{Down-core records}

\subsection{EW0408-85JC}

\subsubsection{Diatoms}

The down-core records of relative abundances of different ecological groups of diatoms in core 85JC are displayed in Fig. 3. Diatom census data are available in supplementary Table 1. North Pacific and temperate oceanic diatom assemblages dominate the core $85 \mathrm{JC}$ diatom record. The latter is more common (typically $>50 \%$ ) below $570 \mathrm{cmbsf}(\sim 11 \mathrm{cal} \mathrm{kyr} \mathrm{BP})$, while the former is more common (>60\%) above $490 \mathrm{cmbsf}$ ( $9.4 \mathrm{cal} \mathrm{kyr} \mathrm{BP})$. Sea ice and sea ice-related diatoms are frequent $(>20 \%)$ in the lowermost biogenic marine sediments of core 85JC, which appears to represent the early part of the Bølling-Alleröd. These sea ice forms decrease rapidly upsection and compose $>3 \%$ of the Holocene diatom assemblages. Shallow marine diatoms and upwelling Thalassiosira together make up $>10 \%$ of the Holocene diatom assemblages, but they are slightly more common prior to $\sim 12$ cal kyr BP. Within the Holocene, upwelling Thalassiosira are somewhat more common ( 6-10\%) between $\sim 6$ and 3 cal kyr BP, based on the currently limited Holocene age control.

\subsubsection{Silicoflagellates}

The down-core records of relative abundances of different ecological groups of silicoflagellates in core 85JC are displayed in Fig. 4. Silicoflagellate census data are available in supplementary Table 2. Dictyocha sp. cf. D. aculeata and D. sp. aff. D. stapedia (large), indicators of warmer waters and/or a deeper thermocline, dominate $(>55 \%)$ the $85 \mathrm{JC}$ record above $\sim 12.8 \mathrm{cal} \mathrm{kyr} \mathrm{BP}$, whereas the upwelling indicator taxa, Distephanus speculum speculum and $D$. speculum minutus dominate (>60\%) the record between 682 and $645 \mathrm{cmbsf}$, which is likely equivalent to the Bølling-Alleröd (14.7 to 12.9 cal kyr BP). During the Holocene, D. speculum speculum and $D$. speculum minutus typically make 


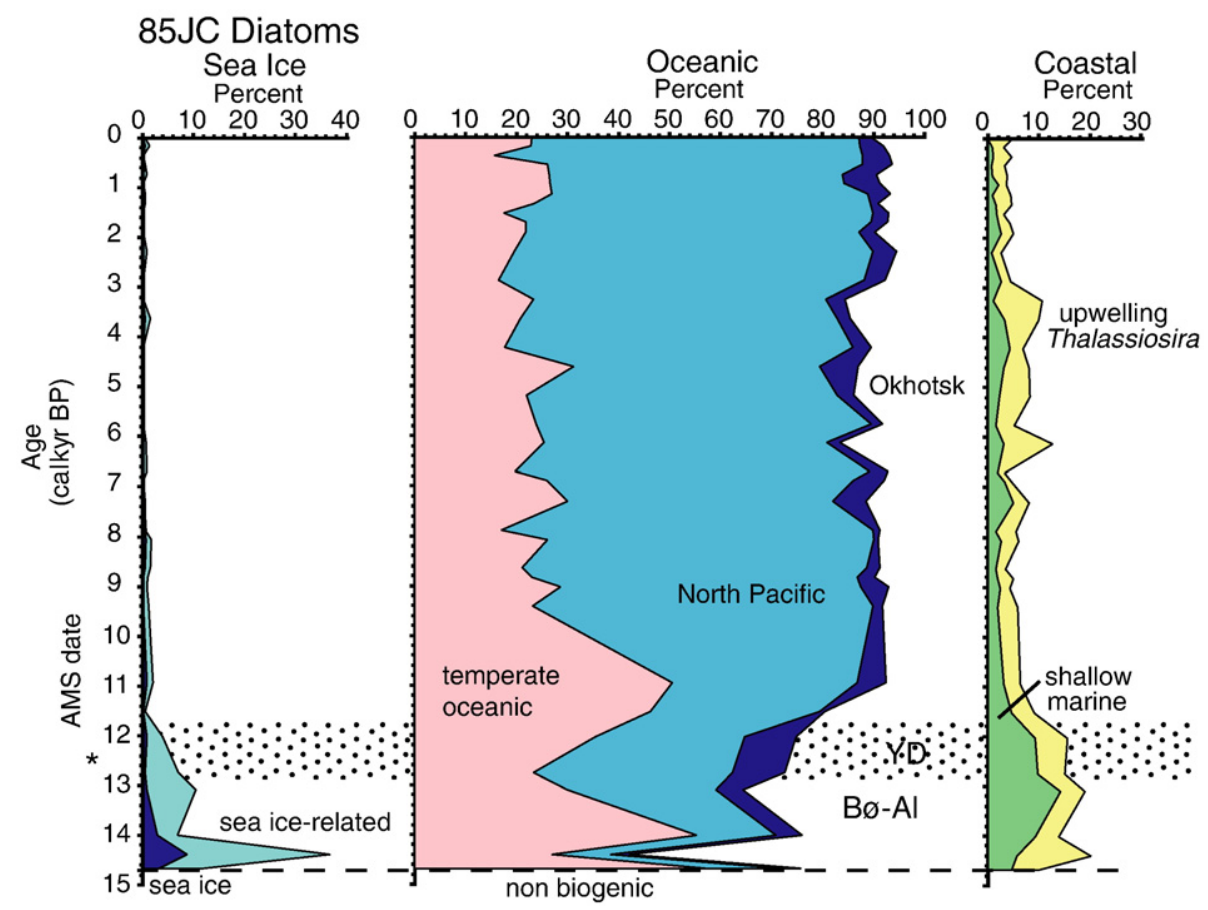

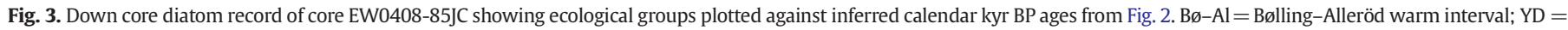
Younger Dryas cold; interval; $\mathrm{cmbsf}=\mathrm{cm}$ below sea floor.

up $>30 \%$ of the silicoflagellate assemblages with abundance increases of $>40 \%$ occurring at $\sim 11.5, \sim 3.6, \sim 1.5$, and $\sim 1.1$ cal kyr BP, based on the rough age model. $D$. octangulatus, a subarctic silicoflagellate, typically composes $>10 \%$ of the $85 \mathrm{JC}$ silicoflagellate assemblages, but it is more common (>15\%) in sediments below 12.5 cal kyr BP.

\subsubsection{Coccoliths}

Coccoliths occur through most of the cored interval from 682 to $59 \mathrm{cmbsf}$, but are only common ( 1 to 4 per field of view at $500 \times$ ) in the older part of the core from 14.7 to $7.9 \mathrm{kyr}$ BP. The younger floras are essentially sparse monospecific Coccolithus pelagicus, with a trace of
Calcidiscus leptoporus. In the older samples, C. pelagicus is common and well represented as complete coccospheres, which are easily observed at $250 \times$ in bright field. Other minor species include Coccolithus pliopelagicus, small Gephyrocapsa spp. and small placoliths (probably Emiliania spp.). The key distinction for these floras is the sparse to common occurrence of Braarudosphaera bigelowii, which occurs as complete dodecahedron braarudospheres, individual pentaliths and trapezoidal crystallites in the interval from 639 to 409 cmbsf ( 12.8 to $\sim 7.9$ kyr BP) (see morphology described in Snavely et al., 1993). B. bigelowii is most common in neritic, lower salinity settings (Bukry, 1974; Aizawa et al., 2004) with preservation enhanced by low dissolved

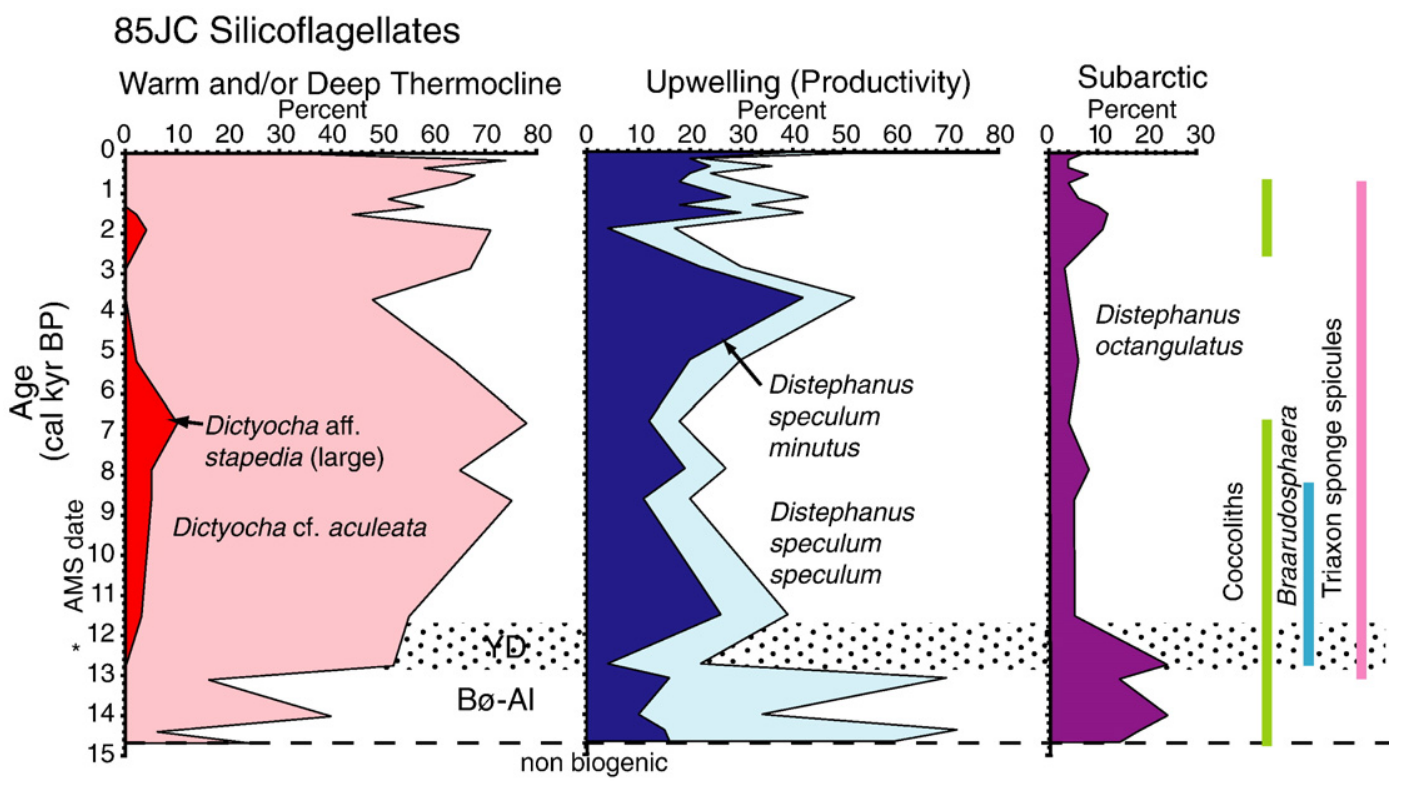

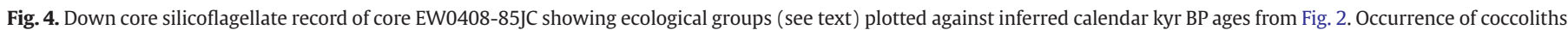
Braarudosphaera, and triaxon sponge spicules is also shown. $\mathrm{B} \emptyset-\mathrm{Al}=$ Bølling-Alleröd warm interval; YD $=$ Younger Dryas cold; interval; cmbsf $=\mathrm{cm}$ below sea floor. 


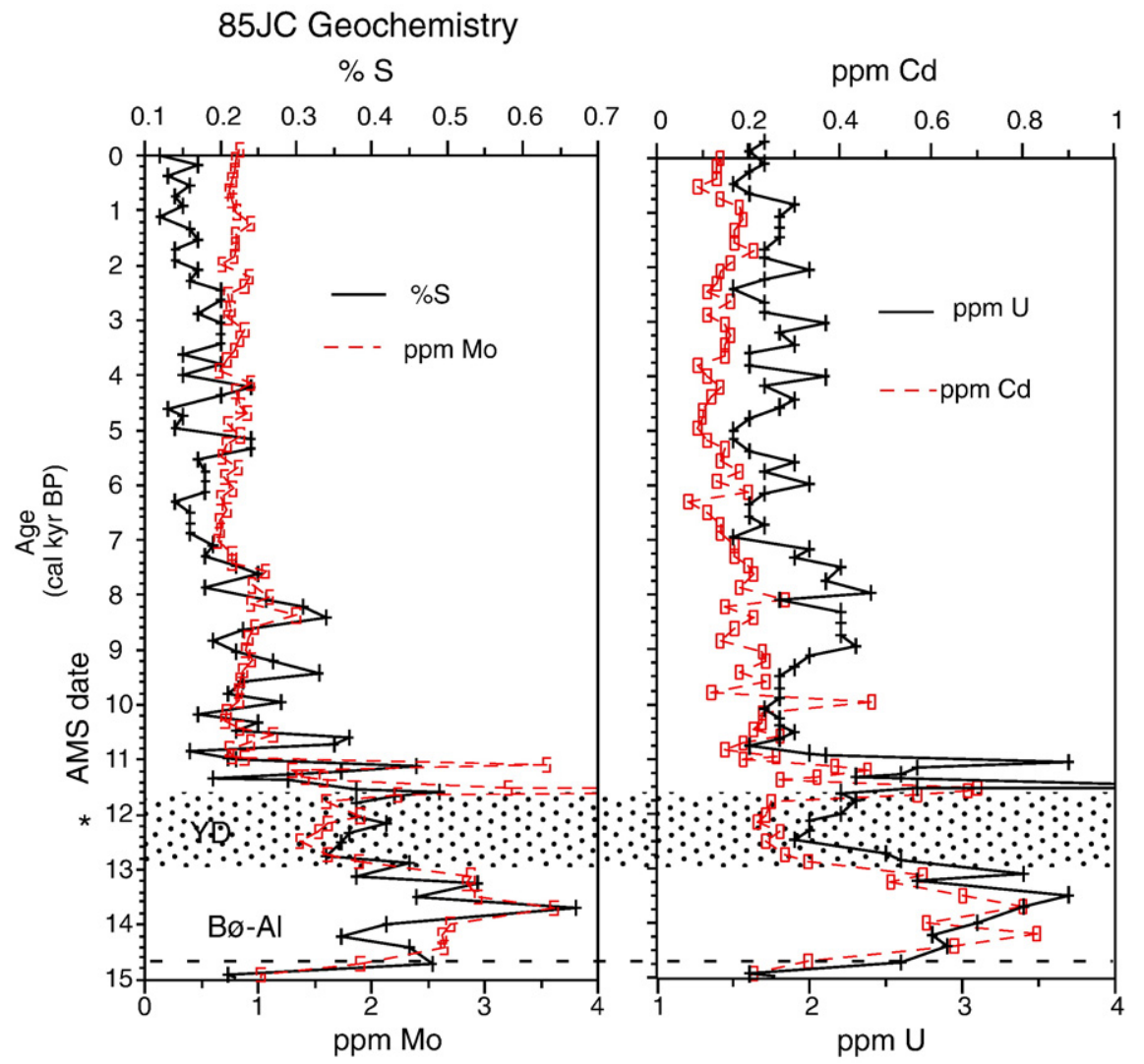

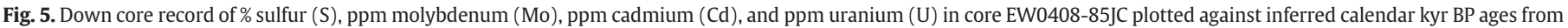
Fig. 2. $\mathrm{B} \emptyset-\mathrm{Al}=$ Bølling-Alleröd warm interval; YD = Younger Dryas cold; interval; cmbsf = cm below sea floor.

oxygen bottom sediments such as the Black Sea. Older Cretaceous (Turonian) blooms were suggested to result from nutrients associated with increased fine siliclastic sediments (Vabenicka, 1999). The blue, green, and orange siliclastic minerals that typify the sediments above the Braarudosphaera interval (49 to $69 \mathrm{cmbsf}$ ) and below in 682 to 668 cmbsf, are rare or missing from the Braarudosphaera interval, indicating a local sedimentation change.

\subsubsection{Geochemistry}

The down-core records of \%S, ppm Mo, ppm Cd, and ppm U in core EW0408-85JC are displayed on Fig. 5. All of the ICP-MS geochemical data are available in supplementary Table 3 . The redox elements S, Mo, $\mathrm{U}$, and $\mathrm{Cd}$ are distinctly higher in the lower part of the core below $\sim 570$ cmbsf ( 11 cal kyr BP) but show little variation above that interval. An interval of reduced values of these proxies between $~ 645$ and $610 \mathrm{cmbsf}$ likely represents the YD (12.9 to $11.7 \mathrm{cal} \mathrm{kyr} \mathrm{BP).} \mathrm{Higher}$ values between 682 and 645 cmbsf correspond with the BøllingAlleröd, while higher values between 607 and 579 cmbsf mark the earliest part of the Holocene.

The terrigerous proxies \% Al and ppm Mn display little variation within the upper $680 \mathrm{~cm}$ of the core $85 \mathrm{JC}$ record. A $1.0 \%$ decline in $\mathrm{Al}$ occurs at $\sim 130 \mathrm{cmbsf}(\sim 2.5 \mathrm{kyr} \mathrm{BP})$.

\subsection{EW0408-66JC}

\subsubsection{Diatoms}

The down-core records of relative abundances of different ecological groups of diatoms in core 66JC are displayed in Fig. 6. Due to the absence of good age control, data are plotted vs. depth. Diatom census data are available in supplementary Table 4 . The core 66JC diatom record below $\sim 600 \mathrm{cmbsf}$ is dominated ( $>35 \%$ ) by upwelling- related Thalassiosira species. Important contributions from sea ice and sea ice-related diatoms ( 20-40\%) occur throughout the 66JC record, especially below $\sim 180 \mathrm{cmbsf}$. Sea ice diatoms increase to $>40 \%$ at $60 \mathrm{cmbsf}$ and North Pacific diatoms increase abruptly to $>40 \%$ in immediately overlying samples. The likelihood of an unconformity at about 60 cmbsf is supported by geochemistry and by a spike in the density values. An abrupt change in diatom assemblages occurs at $\sim 600 \mathrm{cmbsf}$ which possibly coincides with the Bølling-Alleröd/Younger Dryas boundary (12.9 cal kyr BP), where upwelling Thalassiosira decrease upsection from $>40 \%$ to $<30 \%$, while sea ice and sea icerelated diatoms together increase from about $\sim 20 \%$ to $>30 \%$.

\subsubsection{Silicoflagellates}

The down-core records of relative abundances of different ecological groups of silicoflagellates in core 66JC are displayed vs. depth on Fig. 7. Silicoflagellate census data are available in supplementary Table 5. Upwelling indicator taxa, Distephanus speculum speculum and D. speculum minutus dominate $(>60 \%)$ the $66 \mathrm{JC}$ silicoflagellate record. They are especially common $(>80 \%)$ below 700 cmbsf. Dictyocha sp. cf. D. aculeata and D. sp. aff. D. stapedia (large), indicators of warmer waters and/or a deeper thermocline, are more common $(>20 \%)$ above $600 \mathrm{cmbsf}$ in sediments that likely represent the Younger Dryas. The subarctic taxon D. octagulatus show sporadic abundance peaks of $\sim 10 \%$ in sediments above $400 \mathrm{cmbsf}$.

\subsubsection{Coccoliths}

C. pelagicus, with persistent coccospheres, predominates throughout the core from 1378 to $60 \mathrm{cmbsf}$, giving a nearly monospecific flora. Small placoliths (probably Emiliania sp.) occur in only two samples at 700 and 60 cmbsf. No Calcidiscus or Gephyrocapsa occur. These records suggest cold-water, fertile upwelling conditions throughout 


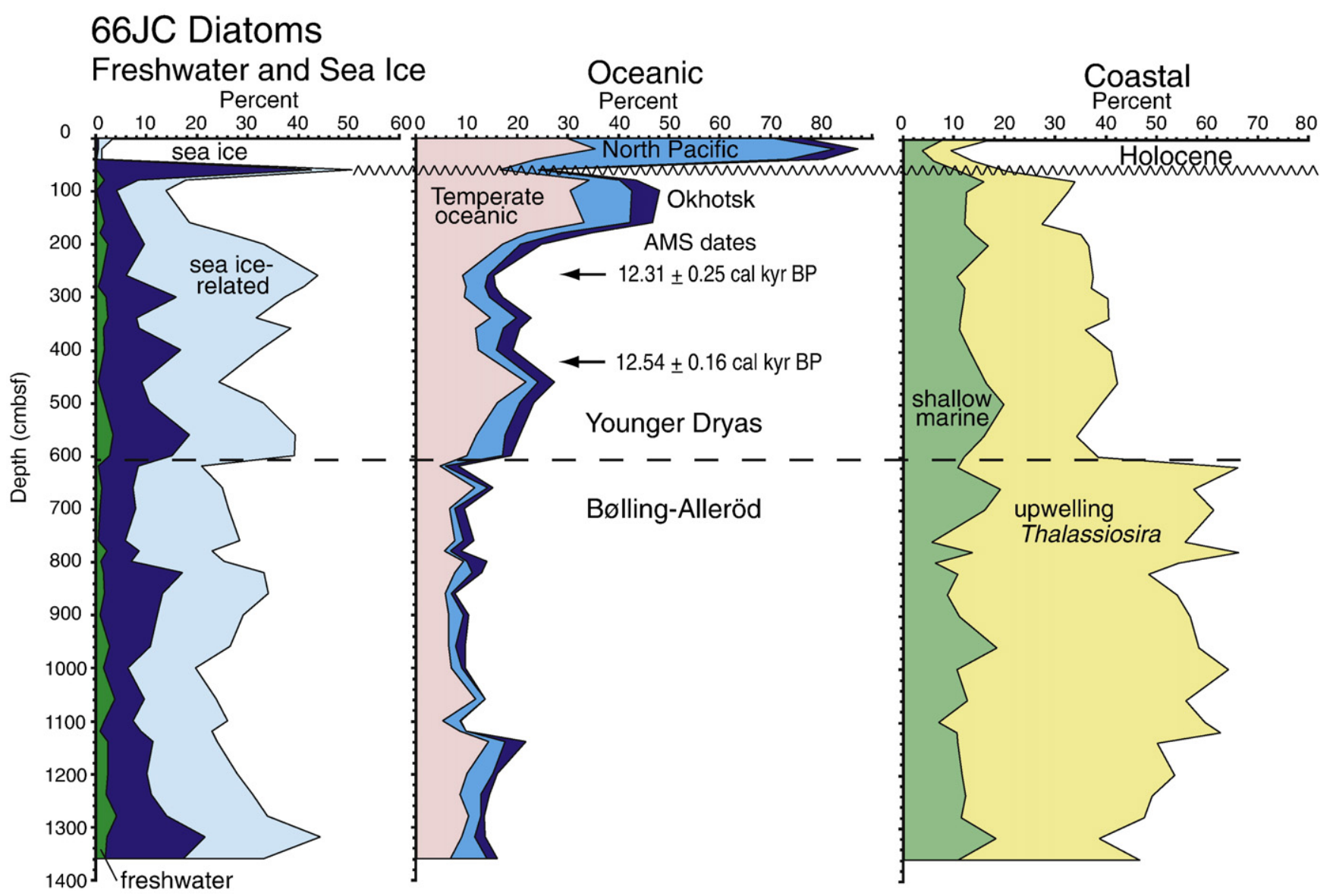

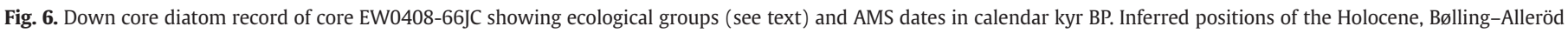
warm interval (Bø-Al), and Younger Dryas cold interval $(\mathrm{YD}) ; \mathrm{cmbsf}=\mathrm{cm}$ below sea floor.

(Aizawa et al., 2004; Parente et al., 2004) and likely carbonate dissolution concentrating resistant $C$. pelagicus. Sedimentation is consistent with blue, green and orange siliclastic grains throughout. C. pelagicus is more numerous, sparse to common, in the upper samples (520 to $60 \mathrm{cmbsf}=$ Younger Dryas?), and rare to sparse in lower samples (1378 to $540 \mathrm{cmbsf}=$ Bølling-Alleröd?).

\subsubsection{Geochemistry}

The wet bulk-density and $\% \mathrm{CaCO}_{3}$ records for core 66 JC are plotted against depth in Fig. 8. The density record varies between about 2.0 and $1.7 \mathrm{~g} / \mathrm{cm}^{3}$, with generally lower and more variable values lying below $\sim 1020 \mathrm{cmbsf}$ and higher, less variable values decreasing upsection above $\sim 1020 \mathrm{cmbsf}$. A conspicuous high-density spike at $\sim 60 \mathrm{cmbsf}$ near a major lithologic change is coincident with an abrupt change in diatom assemblages (Fig. 6), which is suggestive of an unconformity.

The $\% \mathrm{CaCO}_{3}$ record varies between $\sim 1$ and $4 \%$, with generally lower values $(<2.6)$ characterizing the interval below $\sim 480 \mathrm{cmbsf}$. Highest values $(<3 \%)$ occur in the interval between $\sim 440$ and 180 cmbsf, an interval likely equivalent to or within the Younger Dryas.

\subsection{EW0408-11JC}

\subsubsection{Diatoms}

The down-core records of relative abundances of different ecological groups of diatoms in core 11JC are displayed in Fig. 9. Diatom census data are available in supplementary Table 6. Upwelling-related Thalassiosira species, shallow marine, and temperate oceanic diatoms dominate most of the 11JC diatom record. Below $1230 \mathrm{cmbsf}(\sim 12.8 \mathrm{cal}$ kyr BP), however, freshwater and sea ice diatoms together make up $>40 \%$ of the diatom assemblages. Sea Ice-related diatoms gradually decline up section in relatively abundance from $>20 \%$ to $<10 \%$ in the interval between 12.0 and 11.2 cal kyr BP. Shallow marine diatoms vary between $\sim 10$ and $30 \%$ of the diatom assemblages increasing gradually up section between $\sim 11.3$ and to 4.7 cal kyr BP. Temperate oceanic diatoms, on the other hand, decrease up section from values $>30 \%$ between $\sim 11.3$ and 6.8 cal kyr BP to $<20 \%$ in the later part of the Holocene. Correspondingly, the relative contribution of upwellingrelated diatoms increases above $\sim 6.4 \mathrm{cal} \mathrm{kyr}$ BP.

\subsubsection{Silicoflagellates}

The down-core records of relative abundances of different ecological groups of silicoflagellates in core 11JC are displayed in Fig. 10. Silicoflagellate census data are available in supplementary Table 7. The interval above $~ 12.0$ cal kyr BP in 11JC is dominated ( $>90 \%$ ) by upwelling indicator taxa, Distephanus speculum speculum and D. speculum minutus. Minor increases in the warm water/deep thermocline taxa, Dictyocha stapedia and $D$. cf. aculeata, occur between $\sim 6.4$ and 3.0 cal kyr BP. The ratio of the cold water $D$. speculum minutus to $D$. speculum speculum varies considerably in the Holocene record of $11 \mathrm{JC}$, possibly recording the strength of coastal upwelling. The interval between $\sim 14.2$ and 12.9 cal kyr BP contains abundance peaks of Dictyocha sp. aff. D. aculeata and D. octangulatus ( $>15 \%$ ) that stand out from the overlying silicoflagellate record.

\subsubsection{Coccoliths}

Coccoliths occur in the younger part of the section $\sim 8.6$ to $0 \mathrm{kyr} B P$, but are completely missing in samples older than $\sim 8.8 \mathrm{kyr}$ BP. The flora 


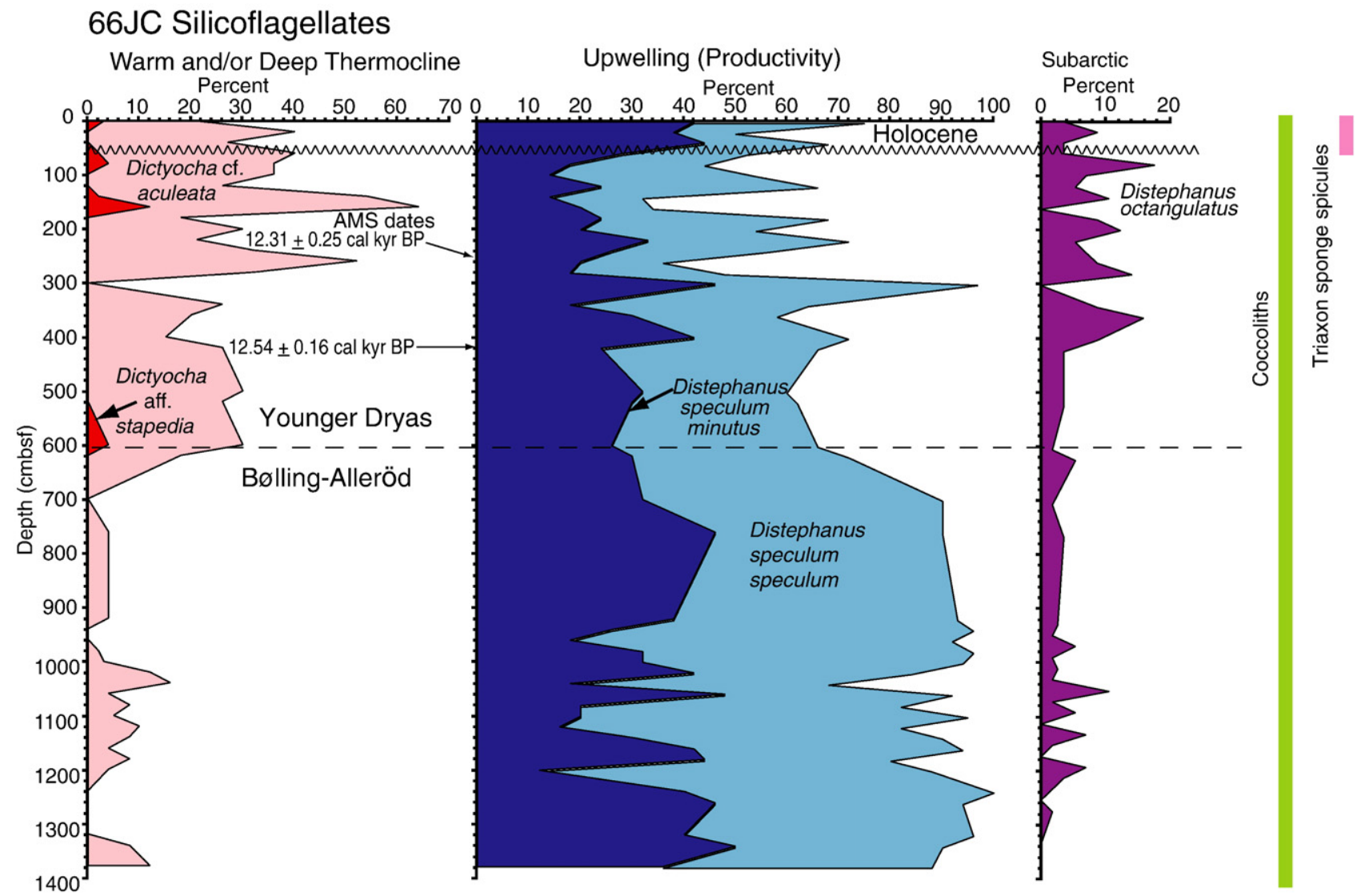

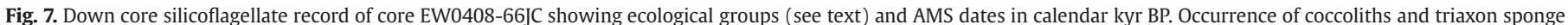
spicules is also shown. Inferred positions of the Holocene, Bølling-Alleröd warm interval (Bø-Al), and Younger Dryas cold interval (YD); cmbsf $=\mathrm{cm}$ below sea floor.

has common C. pelagicus, but is distinguished from that of the other two Alaskan cores by being persistently more diverse. Emiliania spp. and small Gephyrocapsa spp. occur throughout, with sporadic occurrences of C. leptoporus and C. pliopelagicus. No B. bigelowii were recorded.

\subsubsection{Geochemistry}

The ICP-MS geochemical data colleted for core 11JC are available in supplementary Table 8 . The lithophile elements (e.g., Al, Ti, K, Zr, Mg, $\mathrm{Fe}, \mathrm{Li}$, and Rb; Fig. 11) indicate that the detrital clastic fraction (rock debris) decreased gradually upcore. These proxies of terrigenous input show generally similar patterns, with higher values coinciding with the non-biogenic (glacial) sediments below $\sim 1300 \mathrm{cmbsf}$, moderate values that either decrease slightly or show little change between $\sim 1300$ and $810 \mathrm{cmbsf}$ ( 14.7 and $10 \mathrm{cal} \mathrm{kyr} \mathrm{BP}$ ), and lower values that decrease upsection above $\sim 810 \mathrm{cmbsf}$. If $8.5 \% \mathrm{Al}$ in sediments deposited at the bottom of the core is taken to represent $100 \%$ detrital clastic material (average upper continental crust contains $7.8 \% \mathrm{Al}$ ), then the sediments at the top of the core $3.5 \% \mathrm{Al}$ ) contain about $40 \%$ detrital clastic material. The decrease in detrital material (as proxied by $\mathrm{Al}$ ) is matched by increases in $\% \mathrm{CaCO}_{3}$ (Fig. 12) and \% biogenic opal (Addison et al., 2008), indicating that remains of calcareous and siliceous plankton diluted detrital material. Changes in the composition of detrital material at the base of the core (1400 to $1200 \mathrm{cmbsf}$ ) reveal that sources of detrital material changed as relative sea level rose at the glacial-marine transition.

Concentrations of Mo and U (Fig. 12) and Cd (supplementary Table 8) increase gradually above $800 \mathrm{cmbsf}(\sim 10 \mathrm{cal}$ yr BP), reaching maximum values between 500 and $300 \mathrm{cmbsf}$, suggesting that this interval ( 6.2 to $2.8 \mathrm{cal}$ kyr BP) represents a period of maximum productivity and/or DO deficiency. These values decreased above 200 cmbsf ( 2.5 cal kyr BP) indicating that bottom waters became better oxygenated.

\subsection{Actiniscus}

A siliceous endoskeletal dinoflagellate, Actiniscus pentasterias, which produces two internal skeletons (or pentasters) from a gymnodinioid cell, occurs at all three core sites in the Gulf of Alaska. It has been reported with a long Cenozoic geologic record (Locker and Martini, 1986). It ranges from subtropical to cold temperate marine areas, even from the Russian Barents Sea associated with diatoms and silicoflagellates (Okolodkov, 1998).

Pentasters of $A$. pentastrias are minor background microfossils in the southern cores 11JC and 66JC. In core 11JC they occur throughout the section with abundances of 1 to 10 per sample. In core 66JC they are missing from the upper $40 \mathrm{~cm}$, but then occur with low counts of 1 to 3 per sample to the total depth of the sample interval at $1378 \mathrm{cmbsf}$. Pentasters are most abundant in core 85JC, averaging 7 per sample, with a high of 20 in the sample from $69 \mathrm{cmbsf}(\sim 13 \mathrm{cal} \mathrm{kyr} \mathrm{BP})$. A rare hexagonal form occurs in the sample from $639 \mathrm{cmbsf} \sim 12.8 \mathrm{cal} \mathrm{kyr}$ $\mathrm{BP})$. High nutrient levels combined with adequate silicon levels are needed for maximum production of Actiniscus, but they never outproduce silicoflagellates (Boltovskoy et al., 1996).

\subsection{Sponge spicules}

Although an array of various sponge spicule morphologies occur in GOA samples, including widely distributed oxeas, isochelas, sigmas, calthrops, and triods, the latter has a persistent and stratigraphically noteworthy occurrence. The triods recorded for our samples are smooth or simply ornamented (see examples, Bukry (1978). Because the triods had a persistent occurrence through the first core studied, 11JC, (1170 to $300 \mathrm{cmbsf}$ ), their distribution was also noted in the other cores. Surprisingly, triods were only present in the top $60 \mathrm{~cm}$ in 


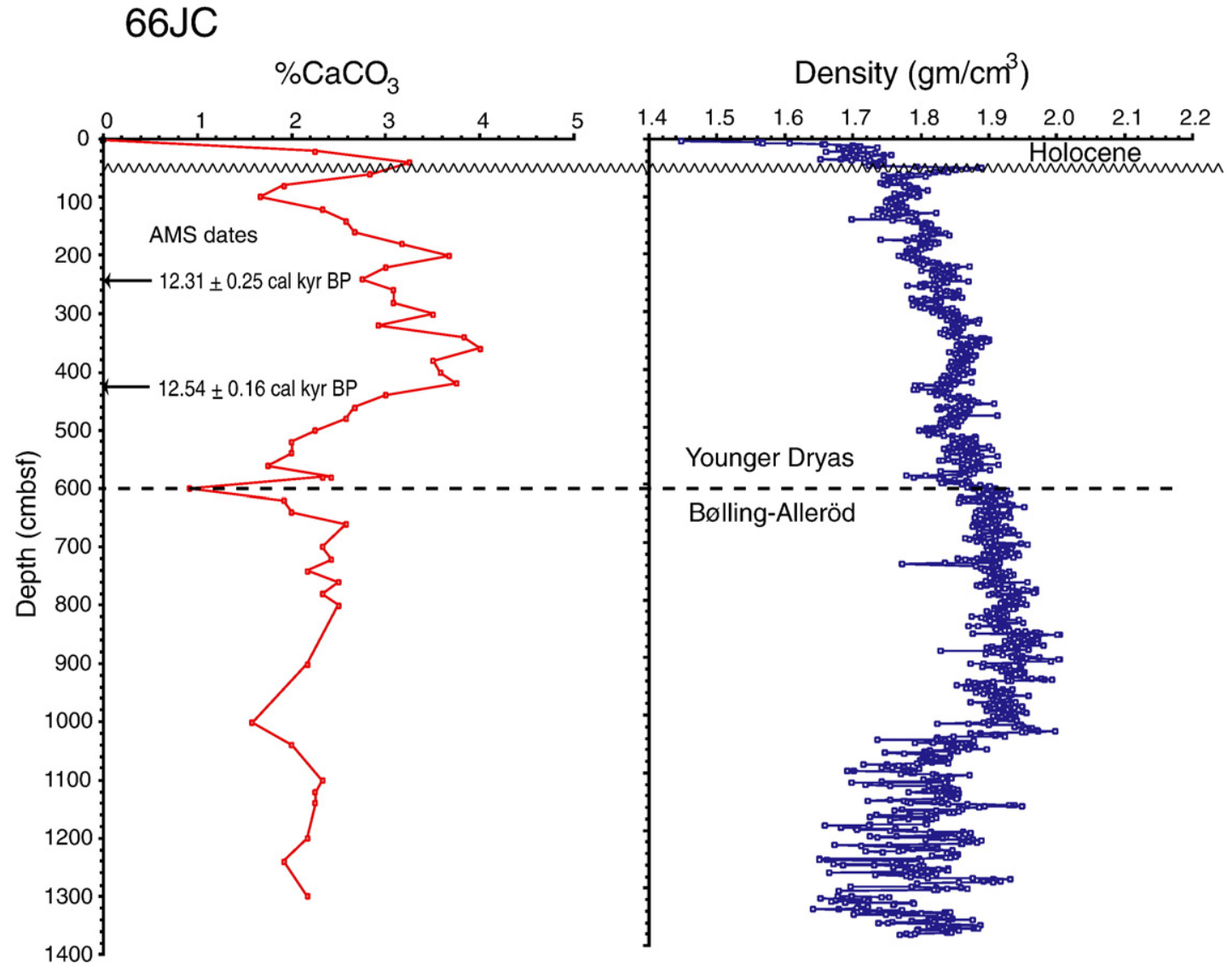

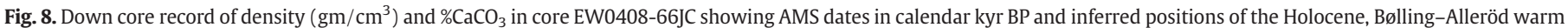
interval ( $\mathrm{B} \varnothing-\mathrm{Al})$, and Younger Dryas cold interval (YD); cmbsf $=\mathrm{cm}$ below sea floor.

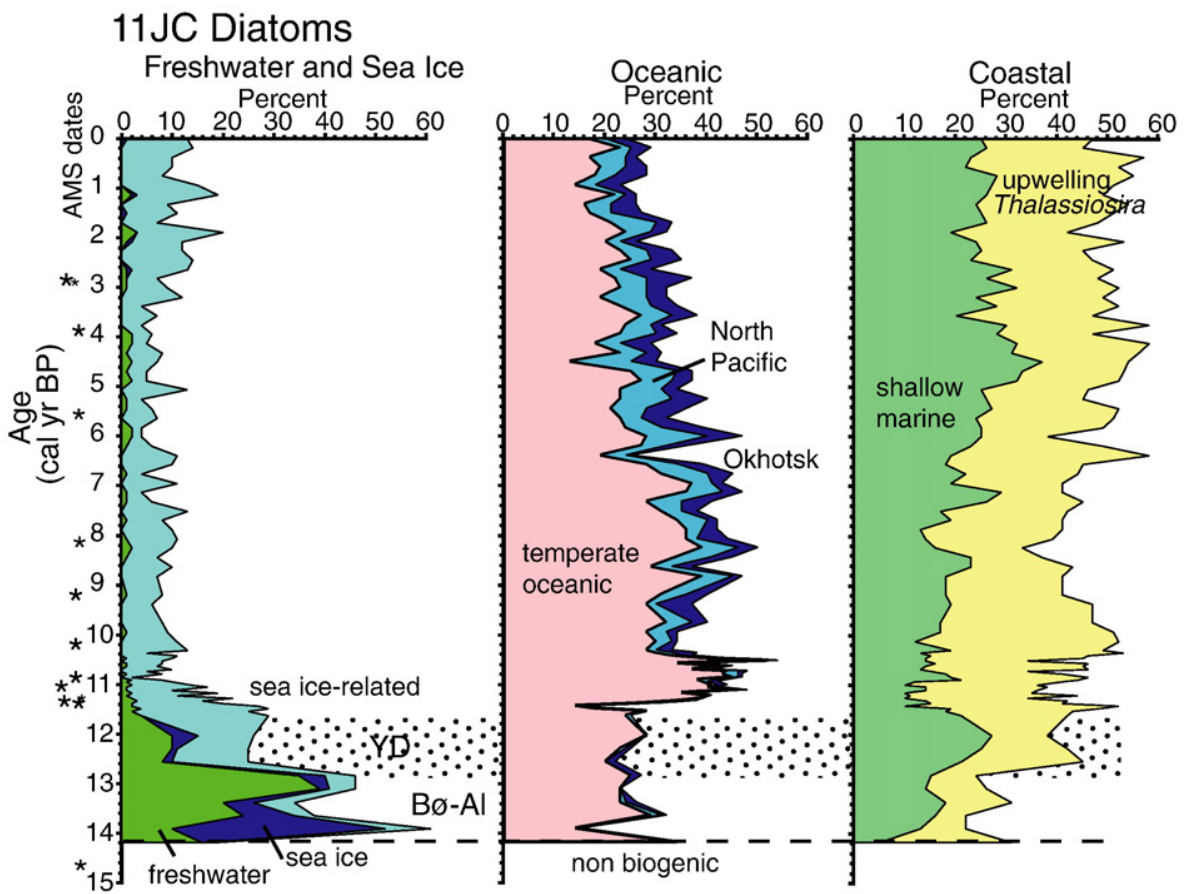

Fig. 9. Down core diatom record of core EW0408-11JC showing ecological groups (see text) plotted against inferred calendar kyr BP ages from Fig. 2. 


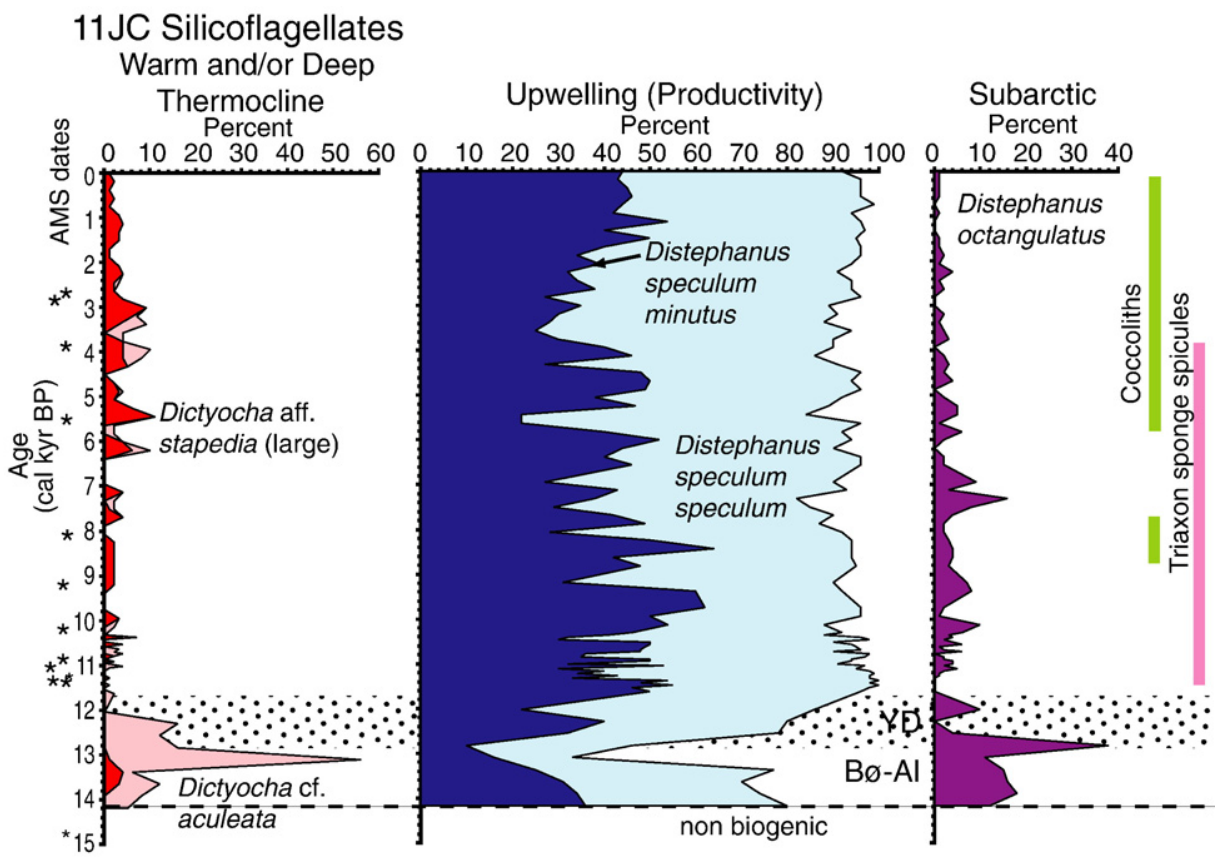

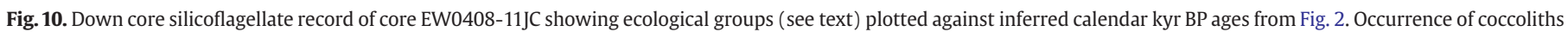
and triaxon sponge spicules is also shown.

11JC Geochemistry

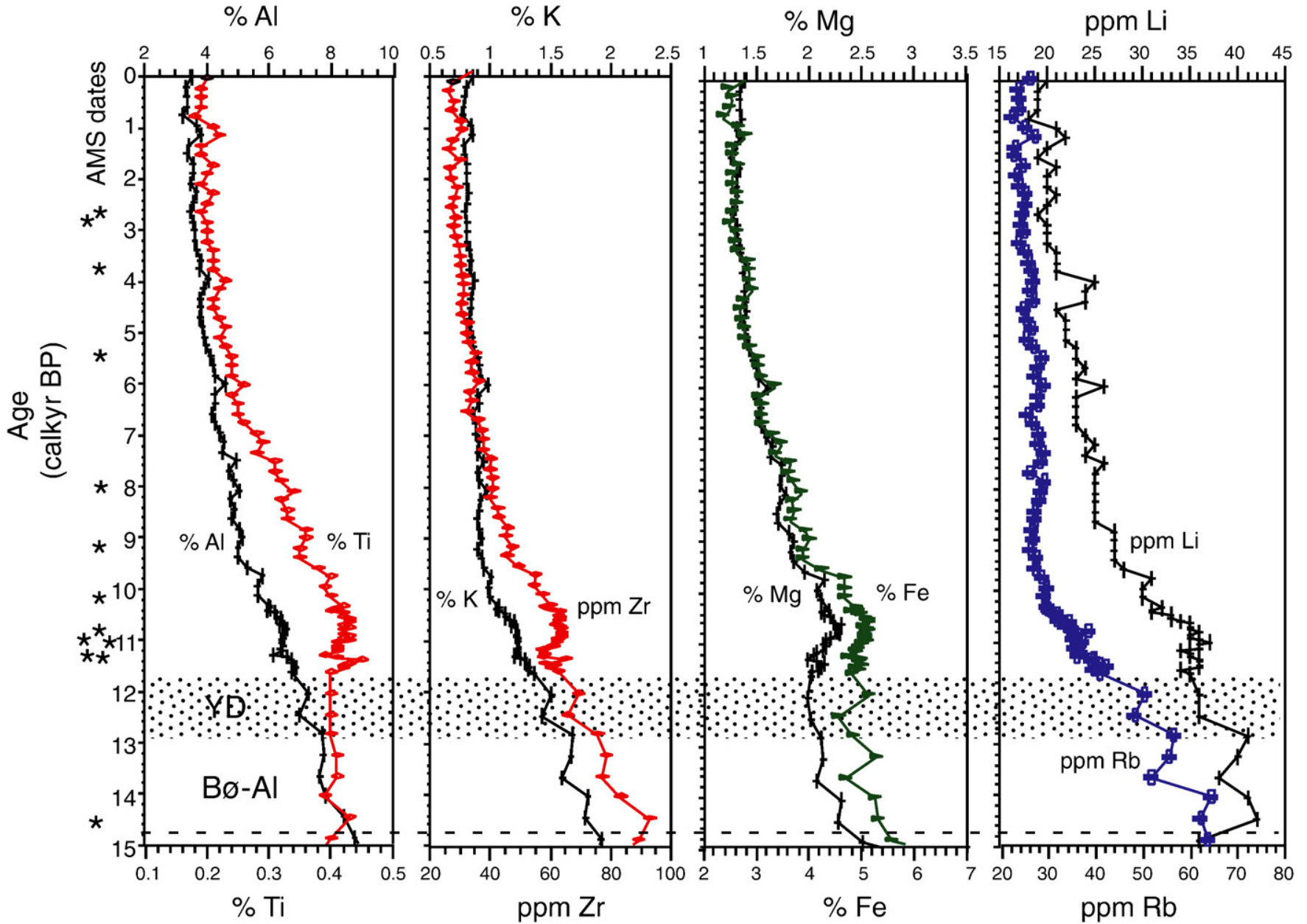

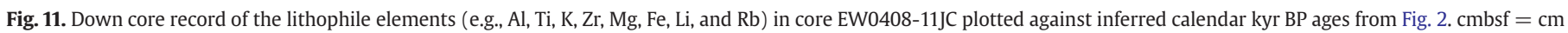
below sea floor. 


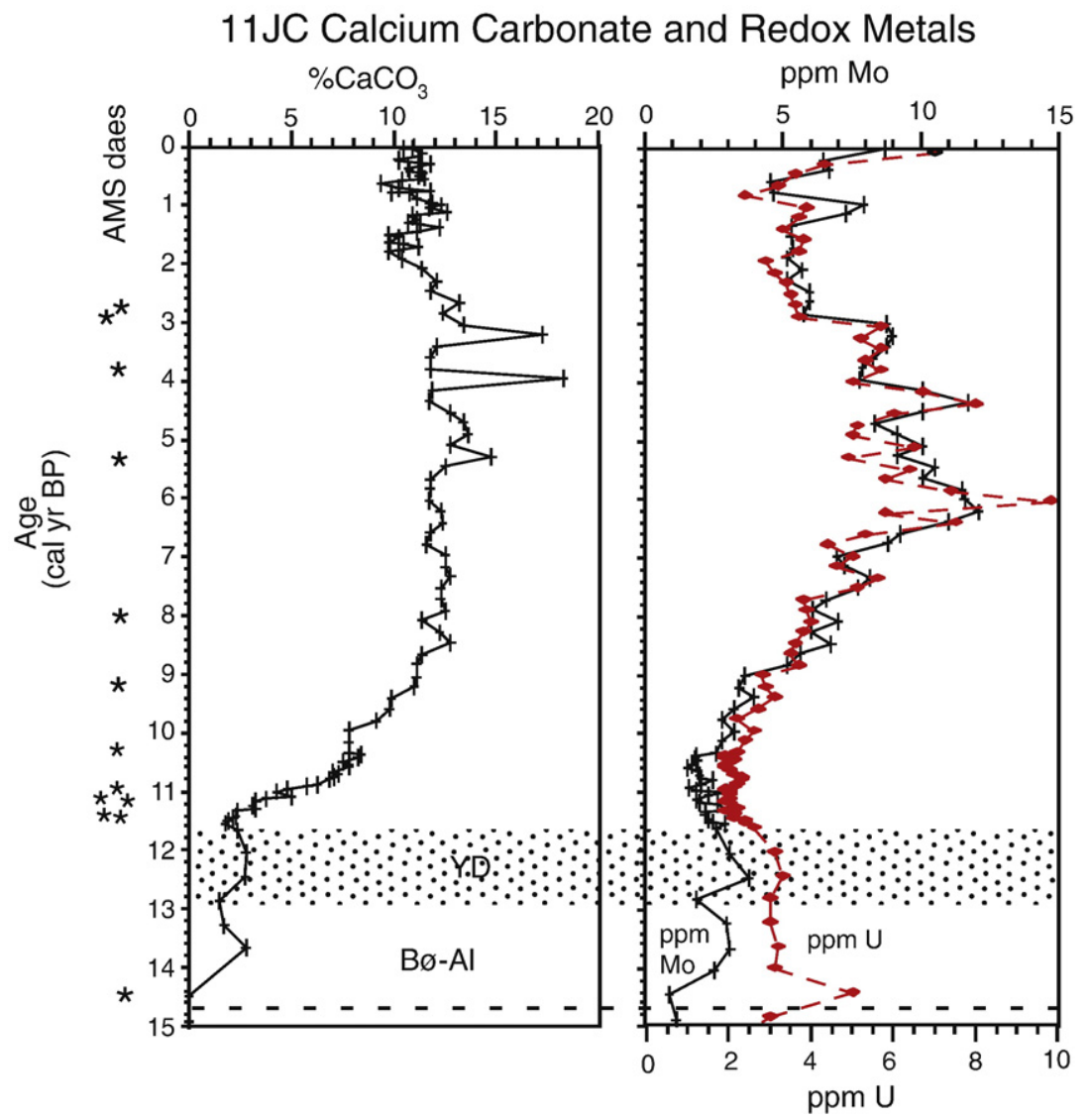

Fig. 12. Down core records of calcium carbonate, Mo, and U in core EW0408-11JC plotted against inferred calendar kyr BP ages from Fig. 2. cmbsf $=$ cm below sea floor.

66JC, which was cored in 483 m water depth. Since coccoliths occur throughout the core below this, there may be an unconformity, because both of the other two cores have intervals where coccolith and triod ranges overlap. They overlap from 705 to $300 \mathrm{cmbsf}$ in 11JC ( $~ 8.8$ to 3.8 cal kyr BP) and from 349 to $59 \mathrm{cmbsf}(\sim 13.1$ to $1.1 \mathrm{cal} \mathrm{kyr}$ $\mathrm{BP})$ in $85 \mathrm{JC}$.

The sponges producing triods may be more common in Alaskan waters than elsewhere in the low-latitude Pacific. ODP and DSDP drilling has shown only rare and sporadic triods in Quaternary sediments of the southwestern Pacific (Andri et al., 2001; Martini, 1981).

\section{Discussion}

\subsection{EW408-85, Kayak Slope}

Core EW0408-85JC on the Kayak Slope (Fig. 1) is not within the high productivity zone of the ACC, but has a deglacial paleoceanographic record that is similar to those of other published northeast Pacific core sites. The geochemical record from core 85JC resembles those from ODP Site 1019 from the northern California margin and P40 and P03 from the central California margin, which also have laminated sediments and elevated concentrations of Mo in the Bø-Al interval indicating dissolved oxygen (DO)-depleted, sulfidic bottom waters (Zheng et al., 2000; Dean, 2007). In addition to elevated concentrations of Mo in Bø-Al sediments, cores P40 and P03 have elevated concentrations of $\mathrm{Cd}$ in that interval, suggesting that the lower dissolved oxygen (DO) conditions in the Oxygen Minimum Zone (OMZ) of North Pacific Intermediate Water (NPIW), indicated by laminated sediments and elevated concentrations of Mo, are more likely due to a higher oxygen demand imposed by decomposition of higher amounts of produced organic matter than to poorer ventilation of NPIW as suggested by Zheng et al. (2000). Based on benthic foraminiferal $\delta^{13} \mathrm{C}$ data at ODP Site 1019, Mix et al. (1999) also concluded that variations in NPIW ventilation were not responsible for the apparent variations in the OMZ on the California margin. The geochemical records from core 85JC also show brief periods of increased productivity and reduced bottom-water DO concentration in the early Holocene that are not found in the California margin records. Elevated concentrations of sulfur in the $\mathrm{B} \emptyset-\mathrm{Al}$ interval in core 85JC are additional evidence for DO-depleted, sulfidic bottom waters.

It is well known that $\mathrm{B} \emptyset-\mathrm{Al}$ and Holocene sediments deposited in the Santa Barbara Basin (SBB; ODP Site 893) are well laminated (e.g., Behl and Kennett, 1996), distinguishing them from bioturbated sediments of the overlying YD interval and the underlying Last Glacial Interval (LGI). Ivanochko and Pedersen (2004) published trace metal data from ODP 893 showing elevated concentrations of Mo and $\mathrm{Cd}$ in $\mathrm{B} \varnothing-\mathrm{Al}$ and Holocene sediments. These elevated $\mathrm{Cd}$ concentrations indicate that increased productivity and resulting biological oxygen demand, possibly in conjunction with poorer ventilation, contributed to lower mid-water DO concentrations.

The elevated concentrations of $\mathrm{Mo}$ and $\mathrm{Cd}$ and laminated sediments in the $\mathrm{B} \emptyset-\mathrm{Al}$ and YD intervals of core $85 \mathrm{JC}$ resemble those in the same intervals in the OMZ all along the California margin, suggesting that similar productivity and low DO conditions existed in the Gulf of Alaska. These same conditions also exist in sediments in the Cariaco Basin off northern Venezuela (Dean, 2007). Productivity and DO conditions in the Cariaco Basin are controlled by the position of the Intertropical Convergence Zone (ITCZ), which, in turn, controls precipitation and the strength of upwelling trade winds.

The teleconnection between the Greenland ice-core record (GISP-2) and the gray-scale and varve records in the Cariaco Basin is well established (e.g., Hughen et al., 1996, 1998; Lea et al., 2003). The correlation between the sediment records in ODP 893 in SBB with GISP-2 is also well established (e.g., Hendy and Kennett, 2003), as is the 
sediment record on the Pacific margin of southern Baja California (Ortiz et al., 2004; Dean et al., 2006).

These correlations of records from the Gulf of Alaska, the margins of the Californias (Alta and Baja), Cariaco Basin, and Greenland ice suggest that the Atlantic and Pacific Oceans were likely linked through the atmosphere, as suggested by Dean (2007). This atmospheric connection is likely related to warmer air temperatures during warmer climate intervals such as the Bø-Al that would have strengthened Hadley and Walker circulation, which, in turn, would have strengthened the subtropical high pressure systems in both the North Atlantic and North Pacific, producing increased upwelling along the margins of California and possibly southeast Alaska.

The relative abundance of both subspecies of the upwelling silicoflagellate, D. speculum, (Fig. 4) supports the geochemical hypothesis that the $\mathrm{B} \emptyset-\mathrm{Al}$ was a more productive interval than the YD. The main differences between the $\mathrm{B} ø-\mathrm{Al}$ and the YD in the diatom data are an increase in the Okhotsk ecological group of Sancetta and Silvestri (1986) and a decline in the temperate oceanic group during the YD (Fig. 3). The diatom data suggests that the waters of the YD above the 85JC core site were more stratified than those of the $\mathrm{B} ø-\mathrm{Al}$, as would be expected if upwelling and biologic productivity were reduced during the YD in comparison with the $\mathrm{B} ø-\mathrm{Al}$.

Increases in the relative abundances of upwelling Thalassiosira between $\sim 6$ and 3 cal kyr BP (Fig. 3) seem to support Anderson et al.'s (2005) proposal that the Aleutian Low was weaker or in a more westward position between $\sim 7.5$ and 4.0 cal kyr BP, given that the 85JC core site (Fig. 1) lies somewhat west of the southeast Alaskan coastal margin. Such an interpretation is consistent with reports of widespread La Niña-like conditions in the North Pacific during the middle part of the Holocene (Koutavas et al., 2002; Barron and Bukry, 2007). On the other hand, $D$. speculum, the upwelling silicoflagellate shows increased relative abundances after $\sim 4$ cal kyr BP (Fig. 4), suggesting that productivity increased over the 85JC core site during the late Holocene. The Cd proxy for productivity is rather low during the past $11 \mathrm{kyr}$, compared to the interval between 15 and 11 cal kyr BP (Fig. 5) and is not supportive of either the diatom or silicoflagellate productivity trends after $\sim 7$ cal kyr BP.

\subsection{EW0408-66JC, Cross Sound}

Core EW0408-66JC lies in the Yakobi Sea Valley, on the southern Alaskan continental shelf just outside Cross Sound. During the LGI, the Yakobi Sea Valley was filled with a lobe of the Cordilleran Ice Sheet (CIS) (Mann, 1986). Seismic studies during the R/V Ewing 0408 cruise suggested that the CIS retreated very rapidly from the continental shelf between about 16 and 13 cal kyr BP (John Jaeger et al., written comm., 2006). Core 66JC contains $>1200 \mathrm{~cm}$ of diatom-rich sediments equivalent to the $\mathrm{B} \emptyset-\mathrm{Al}$ and $\mathrm{YD}$. The CIS must have retreated into Cross Sound by $\sim 15 \mathrm{cal}$ kyr BP or so, as basal sediments in core 66JC are diatom-rich and likely were deposited during the early part of the $\mathrm{B} \emptyset-\mathrm{Al}$ (Figs. 2, 6 and 7). Diatoms and silicoflagellates indicative of coastal upwelling and productivity are common in the $\mathrm{B} \emptyset-\mathrm{Al}$ but decline in abundance in the overlying YD, where oceanic forms become more abundant (Figs. 6 and 7). Sea ice and sea ice-related diatoms are more common in the YD interval ( $30-40 \%$ of the diatom assemblages) than they are during the $\mathrm{B} ø-\mathrm{Al}(\sim 20-30 \%)$, suggesting cooler, more stratified conditions during the YD, similar to the records in core 85JC and elsewhere in the North Pacific. Cooler conditions off southeast Alaska during the YD are consistent with the results of Hetherington and Reid (2003) in the Queen Charlotte Islands and Mathewes et al. (1993) and Patterson et al. (1995) off British Columbia to the south.

An apparent unconformity at $\sim 50 \mathrm{cmbsf}$ in core $66 \mathrm{JC}$ is marked by a spike in density values, a change in lithology, and an abrupt change in diatom assemblages (Fig. 6). This unconformity possibly marks a time early in the Holocene when erosive bottom currents increased over the core site, resulting in a cessation of biogenic sediment deposition. Such a change may have been triggered by falling relative sea level on the nearby coast due to glacial unloading of the margin (Mann and Streveler, 2008), possibly leading to an increased flow of erosive bottom currents down the axis of the Yakobi Sea Valley.

Geochemical data for core 66JC are being compiled independently by Jason Addison. The current data do not extend below $700 \mathrm{cmbsf}$, but they show an almost two fold decline in wt.\% opal (from 10 to $12 \%$ to $\sim 6 \%$ ) occurring at $\sim 500 \mathrm{cmbsf}$ that seems to indicate decreased productivity during the YD.

\subsection{EW0408-11JC, Gulf of Esquibel}

The Gulf of Esquibel is an enclosed basin with only shallow channels connecting it to the Gulf of Alaska proper. Most of these channels are at most $80 \mathrm{~m}$ deep, suggesting that during sea level lowstands of the LGM and deglacial interval, the area would have had limited or no exchange with the open ocean. The diatom record of 11JC reflects relative rising sea level in that the lower $\sim 50 \mathrm{~cm}$ of biogenic sediments ( 14.2 to 12.8 cal kyr BP?) are rich in freshwater and sea ice diatoms (Fig. 9). Sea ice and sea ice-related diatoms decline during the overlying $200 \mathrm{~cm}$ ( 12.8 to $11.1 \mathrm{cal} \mathrm{kyr} \mathrm{BP})$, as coastal upwelling and oceanic diatoms become more common.

The excellent age control on the early Holocene of core 11JC (Table 1) seems to indicate an abrupt decline in sedimentation rates from at least $280 \mathrm{~cm} / \mathrm{kyr}$ between $\sim 1185$ and $\sim 820 \mathrm{cmbsf}$ (11.6 to $10.3 \mathrm{ca}$. kyr BP) to $\sim 80 \mathrm{~cm} / \mathrm{kyr}$ above $820 \mathrm{cmbsf}$ ( $10.3 \mathrm{cal} \mathrm{kyr} \mathrm{BP)} \mathrm{(Fig.} \mathrm{2).} \mathrm{This} \mathrm{abrupt}$ change, which is probably more gradual than shown on Fig. 2, likely reflects a critical time when the rising regional sea level resulted in decreased delivery of terrigenous elements (Fig. 11) to the core site.

Diatoms and silicoflagellates both suggest that coastal upwelling or high productivity was dominant at the Gulf of Esquibel 11JC core site during the past $11 \mathrm{kyr}$ with cycles occurring at least every $~ 0.5 \mathrm{kyr}$ (Figs. 9 and 10). The Mo and U data (Fig. 12) argue that the interval between $\sim 6.5$ and 2.8 cal kyr BP represents a period of maximum productivity and/or DO deficiency. Interactions between changes in productivity and the oxygenation of the Gulf of Esquibel water column may obscure simple interpretations of $\mathrm{Cd}, \mathrm{Mo}$, and $\mathrm{U}$ concentration data. If productivity driven, this conclusion may contrast with Anderson et al.'s (2005) hypothesis that the wintertime Aleutian Low was weakened and in a more westerly position at that time, as one would expect reduced productivity under such conditions. However, diatom and silicoflagellate proxies do not reveal major changes in the strength of coastal upwelling (high productivity) during the Holocene, but the contribution of upwelling-related diatoms increases somewhat during the past $\sim 6.4 \mathrm{cal}$ kyr BP. (Figs. 7 and 8 ). Thus, the onset of higher productivity and more anoxic conditions at $\sim 6.5$ cal kyr BP may coincide with this diatom productivity increase, but the change to more oxic conditions at $\sim 2.8$ cal kyr BP does not appear to correspond with a decline in productivity.

Addison et al. (2008) report that the opal accumulation rate increases steadily from $\sim 3 \mathrm{~g} / \mathrm{cm}^{2} / \mathrm{yr}$ at $\sim 9.5 \mathrm{cal} \mathrm{kyr}$ BP to maximum values $\sim 4 \mathrm{~g} / \mathrm{cm}^{2} / \mathrm{yr}$ between $\sim 3.2$ cal $\mathrm{kyr}$ BP and the present. Enhanced productivity in the Gulf of Esquibel during the later part of the Holocene agrees with their opal data from three other cores taken along the southeast margin of Alaska. An enhancement of ENSO cycles in the Pacific during the late Holocene (Rodbell et al., 1999; Clement et al., 2000; Liu et al., 2000; Moy et al., 2002) should lead to increased productivity along the southeast margin of Alaska (Addison et al., 2008), especially compared to the mid Holocene.

\section{Conclusions}

High-resolution ocean-climate records of the past 15,000 years were studied in three cores from the Gulf of Alaska (GOA) using diatoms, silicoflagellates, and geochemistry. EW0408-85JC in an oceanic setting from the Kayak Slope in the northern GOA contains a deglacial record that resembles those of the California margin. A 
sharp transition from glacial to biogenic marine sediments marks the base of the Bølling-Alleröd warm interval at $14.7 \mathrm{cal} \mathrm{kyr} \mathrm{BP,} \mathrm{where} \mathrm{it} \mathrm{is}$ coincident with the occurrence of the base of laminated sediments. A geochemical proxy for productivity (Cd) and proxies for oxygendeficient, sulfidic bottom-water conditions ( $\mathrm{S}, \mathrm{U}$, and Mo) increase and remain relatively high in the laminated sediments of the $\mathrm{Bø}-\mathrm{Al}$ interval, similar to many other $\mathrm{B} \emptyset-\mathrm{Al}$ records in the North Pacific, Gulf of California, and Caribbean Sea. A decrease of these geochemical proxies between $\sim 645$ and $610 \mathrm{~cm}$ occurs in non-laminated sediments and is coincident with the Younger Dryas cold inteval $(12.9$ to $11.7 \mathrm{cal}$ kyr BP). Subsequent peaks in Cd, S, U, and Mo occur between 610 and $580 \mathrm{~cm}$ during the earliest part of the Holocene, again similar to an increase biologic productivity commonly recorded in the North Pacific. After $\sim 11$ cal kyr BP, the Holocene is dominated by oceanic North Pacific diatoms and silicoflagellates in sediments that accumulated under well oxygenated bottom-water conditions, resembling the diatom record at ODP Site 1019 off northern California (Barron et al., 2003). Increases in the relative abundances of upwelling Thalassiosira between $\sim 6$ and 3 cal kyr BP generally support Anderson et al.'s (2005) proposal that the wintertime Aleutian Low was in a more westward position between 7.5 and 4.0 cal kyr BP.

Cores EW0408-66JC ( $57^{\circ} 52^{\prime} \mathrm{N}, 137^{\circ} 6^{\prime} \mathrm{W}, 426 \mathrm{~m}$ water depth) in the Cross Sound area and EW0408-11JC $\left(55^{\circ} 38^{\prime} \mathrm{N}, 133^{\circ} 16^{\prime} \mathrm{N}, 183 \mathrm{~m}\right.$ water depth) in the Gulf of Esquibel together make up an expanded, composite record of the past 15,000 years along the SE Alaskan margin. Both lie within the coastal area affected by the Alaskan Coastal Current, suggesting that they should record the history of coastal circulation.

Core 66JC bottoms in marine, biogenic sediments that are likely equivalent with the $\mathrm{B} ø-\mathrm{Al}$ (14.7-12.9 cal kyr BP). Additional radiocarbon dates are needed in the lower portions of the core to confirm the $\mathrm{B} \emptyset-\mathrm{Al}$ age of the sediments, and a minimum age for deglaciation. Diatoms and silicoflagellates indicative of coastal upwelling are relatively common between $\sim 1380$ and $610 \mathrm{cmbsf}$, an interval probably equivalent to the $\mathrm{B} \emptyset-\mathrm{Al}$. They decline in abundance in the interval between $\sim 610$ and $80 \mathrm{cmbsf}$, during the YD, supporting the hypothesis that biological productivity declined during the YD. A likely unconformity at $\sim 60 \mathrm{cmbsf}$ in core $66 \mathrm{JC}$ coincides with an abrupt increase in North Pacific oceanic diatoms, suggesting that it represents the YD-Holocene boundary. This unconformity likely marks a time near the end of the YD when bottom currents became more erosive over the 66JC core site.

Core EW0408-11JC in the Gulf of Esquibel contains an expanded record of Holocene conditions. The glacial to biogenic marine sediment transition at $1280 \mathrm{cmbsf}$ is likely controlled by rising sea level and appears to coincide with the base of the Holocene (11.7 cal kyr BP). Freshwater and sea ice-related diatoms are common in the lower part of the core. Upwelling-related diatoms and silicoflagellates quickly increase in relative abundance upsection and dominate the record of the past 11 kyr. Geochemical productivity proxies $\mathrm{CaCO}_{3}$ and $\mathrm{Cd}$, and anoxia proxies $U$ and Mo increase upcore, reaching peak values between $\sim 6.5$ and $2.8 \mathrm{cal} \mathrm{kyr}$ BP. The diatom record of the past $11 \mathrm{kyr}$ displays fluctuations in the relative contributions of upwelling vs. oceanic taxa, with upwelling taxa increasing above $~ 511 \mathrm{cmbsf}$ (6.4 cal kyr BP).

\section{Acknowledgements}

Appreciation is due to Alan Mix and John Jaeger and the crew and scientific staff of NSF-sponsored, the 2004 R/V Maurice Ewing Cruise 0408. Tom Ager and the staff of the Oregon State core repository are thanked for taking the samples. Tom Ager is thanked for providing for the numerous discussions on the climate of Alaska and for providing access to the Leech Lake material. This manuscript benefited from the reviews of Scott W. Starratt and Tom Ager of the USGS. The USGS Earth Surface Dynamics Program provided funding to Barron, Bukry, and Dean. Funding to Addison came in part from a University of Alaska Fairbanks (UAF) Center for Global Change Student Award and International Polar Year (IPY) Student Traineeship both funded by the Cooperative Institute for Arctic Research (CIFAR) through cooperative agreement NA17RJ1224 with the National Oceanic and Atmospheric Administration (NOAA). Funding for Finney and additional funding for Addison was provided by NSF grant OCE-0351075.

\section{Appendix A}

\section{List of diatom taxa recorded}

Actinocyclus curvatulus Janice (illustrated in Pl. I, Fig. 7) Azpeitia tabulariz (Grunow) Fryxell et Sims

Bacteriosira fragilis Gran

Coscinodiscus marginatus Ehrenberg

Coscinodiscus radiatus Ehrenberg

C. sp. (large) - includes C. oculus-iridis Ehrenberg, C. perforatus Ehrenberg

Cyclotella spp. - includes C. stylorum Brightwell (pl. I, Fig. 11) and C. striata (Kützing) Grunow.

Fragilariopsis cylindrus (Grunow) Krieger

F. doliolus (Wallich) Medlin

F. oceanica (Cleve) Hasle; synonym Nitzschia grunowii Hasle Neodenticula seminae (Simonsen et Kanaya) Akiba et Yanagisawa Nitzschia sp. cf. N. bicapitata Cleve

Porosira glacialis (Grunow) Jøergensen (pl. I, Fig. 9)

Pseudo-nitzschia spp.

Rhizosolenia spp. Includes R. styliformis, $R$. hebetata f. semispina, and other unidentified $R$. spp.

R. hebetata Bailey

Stephanopyxis spp. includes S. turris (Arnott in Greville) Ralfs in Pritchard

Thalassionema nitzschioides (Grunow) Van Heurck

Thalassiosira eccentrica (Ehrenberg) Cleve (pl. I, Fig. 1)

Includes T. symmetrica Fryxell and Hasle (1972)

T. gravida Cleve

T. hyalina (Grunow) Gran (pl. I, Fig. 6)

T. lineata Jousé.

This taxon was tabulated separately only in core EW0408-85JC where it likely includes T. anguste-lineata (A. Schmidt) G. Fryxell and Hasle (1977). In the other cores these taxa are tabulated with undifferentiated Thalassiosira spp.

T. nordenskioeldii Cleve. See Hasle (1978) (pl. I, Fig. 4)

T. oestrupii (Ostenfeld) Hasle

T. pacifica Gran et Angst. See Hasle (1978) (pl. I, Figs. 5 and 8)

T. trifulta Fryxell; synonym T. latimarginata Makarova (pl. I, Fig. 10)

T. small spp. (pl. I, Figs. 2 and 3)

Tabulated are small $(<10 \mu \mathrm{m})$ Thalassiosira that likely include T. angulata (Gregory) Hasle, Thalassiosira decipiens (Grunow; Grunow in Van Heurck) E. Jørgensen, T. pacifica, and Minidiscus spp.

T. spp.

Thalassiothrix longissima Cleve et Grunow

Other planktic - other planktic diatoms not tabulated separately. Actinoptychus spp. Includes A. senarius (Ehrenberg) Ehrenberg and A. bipunctatus Lohman

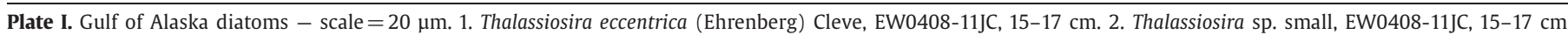

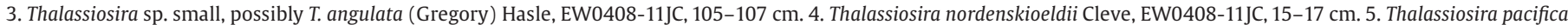

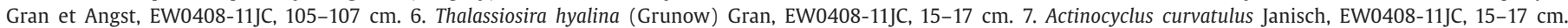

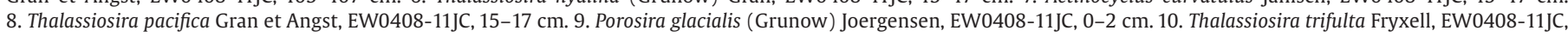
15-17 cm. 11. Cyclotella stylorum Brightwell, EW0408-11JC, 0-2 cm. 


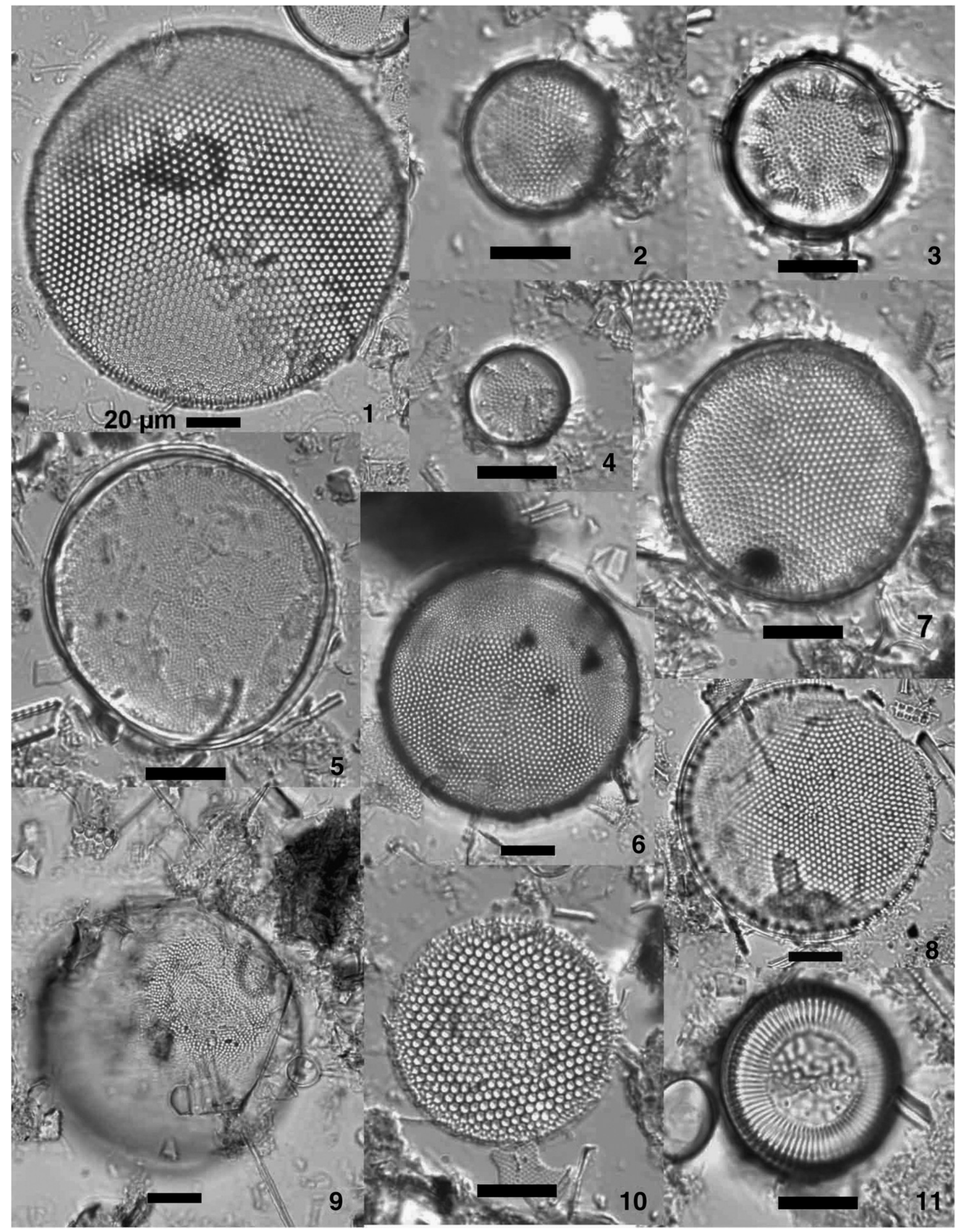


Paralia sulcata (Ehrenberg) Cleve

Benthic

Freshwater planktic (Stephanodiscus, Aulacoseira)

Freshwater benthic

Reworked - fossil diatoms that are reworked.

List of silicoflagellate taxa recorded (D. Bukry, author)

Dictyocha sp. cf. D. aculeata (Lemmermann) Dumitrica 1973 s.l. (pl. II, Figs. 3 and 4).

Dictyocha subarctios (Ling, 1970), p. 95, 96, pl. 18, Figs. 16-18; pl. 19, Fig. 1-4.

D. sp. aff. D. stapedia Haeckel 1887 (large form) (pl. II, Figs. 1 and 2).

Examination of a series of Pacific Coast ocean cores from Santa Barbara Basin $\left(33^{\circ} \mathrm{N}\right)$ north to the GOA $\left(60^{\circ} \mathrm{N}\right)$ has shown that typical small specimens of $D$. stapedia s.s. disappear from Dictyocha populations. Surface sediment surveys show the same reduction (Poelchau, 1976). The two large Dictyocha in northern cores are $D$. aculeata and a large new species resembling $D$. stapedia. This new cold water Dictyocha, recorded as D. sp. aff. D. stapedia (large) has strut/ring attachment asymmetry like D. stapedia, but is 23 times larger and has accessory pikes on the struts at the strut/ring junction. It also lacks the diagnostic spire on the apical bar. The occurrence of this new species in northern floras without any typical D. stapedia s.s. specimens show that it is probably an independent cold-water indicator.

Prior work by Poelchau (1976) showed a minor presence of a large species "Dictyocha messanensis forma spinosa of Lemmermann" in the central part of the GOA. But that form is different in having a spire on the apical bar and extra pikes midway along the struts. Further, Poelchau (1976) noted the extreme variability of that taxon with a high frequency of 5- and 6- spine variants. Our coastal species is distinctive in being very conservative quadrate with extra pikes located only low on the struts and no apical spire.

Distephanus floridus (Bukry, 1985) (pl. II, Fig. 15).

This is a mid- to high-latitude species identified in the North Pacific at DSDP Sites 310,191, 184 and 173. It is most abundant in older middle Pleistocene floras (Ling, 1975; Bukry, 1985). In core 66JC it is sporadic and minor at $0-2 \%$, occurring in both warm and cool floras. It is even sparser in core 11JC, where it only occurs below $1200 \mathrm{cmbsf}$ and above $300 \mathrm{cmbsf}$ in samples where the relative abundance of Distephanus speculum minutus is low. In core 85JC $D$. floridus only occurs in the lowermost two samples at 1 and 2\%. These distributions suggest it favors reduced upwelling.

D. octangulatus Wailes 1939 (pl. II, Figs. 5 and 6).

Apical ring sizes vary widely and are only rarely substituted by an apical bar. The morphology of the skeleton is well described by Poelchau (1976). It is considered a deep-water taxon (E. Venrick, oral communication, 2006).

D. octangulatus (bar).

Instead of the typical apical ring, the four struts support an apical bar. This is a rare variation.

Distephanus pseudofibula (P. Schulz) (Bukry, 1975).

Similar to $D$. speculum, but with apical bars instead of an apical ring.

Distephanus quinquangellus (Bukry and Foster, 1973).

Pentagonal specimens of Distephanus were not tabulated, but they were noted in cores 66JC and 11JC. Apical rings are small to moderate. Only single specimens were noted in eight samples from 66JC, and these tended to be in warm-water samples where $D$. speculum speculum predominated over $D$. speculum minutus and specimens of Dictyocha were more common. In core 11JC specimens of D. quinquangellus occur at very low frequency (1-2 per sample), without a clear preference to either warm or cool-water floras.

Distephanus speculum elongatus (Bukry, 1975). A minor highlatitude subspecies originally described from DSDP 303 in the North Pacific.
Distephanus speculum minutus (Bachmann) (Bukry, 1976), emended by Bukry (1981) (pl. II, Figs. 11 and 12).

Distephanus speculum minutus, as emended by Bukry (1981), is a form that has an apical ring that in plan view is contiguous or overlaps the basal ring. This differs from similarly constructed $D$. speculum speculum by having nearly vertical struts connecting the two rings, instead of inclined, easily visible struts that connect the smaller apical rings of that taxon. Bukry and Monechi (1985) showed North Pacific $D$. quinquangellus, $D$ speculum minutus and $D$. speculum speculum specimens with and without basal-ring pikes. Because of mixed associations of similar specimens with large, small, or no pikes that feature has not been used as a species defining distinction (for example, even at the lower forma level, both types have been combined for a single taxon, compare Bachmann's new forma in Loeblich et al., 1968, pl. 52, Figs. 2639). Pikes might eventually show some intraspecific ecophenotypic utility. Also, many specimens can have coronatid ornamentation, with small pikes on the periphery of the apical ring on inter-strut ring segments; these are considered part of normal phenotypic variation for this subspecies. But ring, spine and strut morphology are the basis for most species and subspecies definition. Surface texture variations may also prove useful for ecology and evolution studies (Bukry and Monechi, 1985; Kobayashi, 1988; Bukry, 1995).

Distephanus speculum minutus increases its relative numbers poleward compared to populations of D. speculum s.s., (Bukry, 1976, 1981, 1986, 1987). Studies of Holocene silicoflagellate populations in the eastern North Pacific (Bukry, unpublished data) confirm that D. speculum minutus is restricted to cooler waters north of Pt. Conception $\left(34^{\circ} \mathrm{N}\right)$ with its relative abundance increasing northward to piston core EW0408-07JC from offshore waters of Cordova Bay, Alaska $56.96^{\circ} \mathrm{N}$ ). Thus, increased percentages of $D$. speculum minutus, as at ODP 1019 and EW9504-17PC off northern California, are inferred to reflect cooling of surface waters. This cool-upwelling association is also seen downcore in our three GOA cores. For example, at EW040866JC, the sample sequence of 1080,1060 , and $1040 \mathrm{cmbsf}$ has high D. speculum minutus and low D. aculeata numbers at $1060 \mathrm{cmbsf}$, whereas the warmer floras below $1080 \mathrm{cmbsf}$ and above $1040 \mathrm{cmbsf}$ have only half as many $D$. speculum minutus and twice as many D. aculeata.

Distephanus speculum ornamentatum (Ehrenberg, 1844) Bukry, n. comb. (pl. II, Fig. 14).

Basionym: D. ornamentatum (Ehrenberg, 1844), p. 80. Figured by Ehrenberg (1854), pl. 22, Fig. 49.

Seven-sided $D$. speculum ornamentatum specimens are most numerous (up to 11\%) in the upper samples from core EW0408-11JC $\left(155^{\circ} \mathrm{N}\right)$. This is in contrast to the Oregon and California offshore cores EW9504-17PC and ODP1019C, where it is rare and sporadic (Barron and Bukry, 2007). Further, Kozo Takahashi (written communication, 2006) has reported it in sea-ice areas in the Arctic Ocean at up to $71 \%$.

Seven-spined members of the $D$. speculum plexus are, herein, classified as D. speculum ornamentatum (Ehr.). Alaska specimens have basal pikes, regular symmetry, and the same size and proportions as the associated master species $D$. speculum speculum. A check of Ehrenberg's drawings in Loeblich et al. (1968) and Locker's (1974) refiguring of the original $D$. septenarius shows that this taxon has unequal nonsymmetric spines, no basal pikes and a rounded basal ring, unlike $D$. speculum. Distephanus speculum ornamentatum has a polygonal basal ring with basal pikes and regular symmetry. Like D. speculum minutus, I (D. Bukry) favor recognizing ecophenotypes within $D$. speculum because their appearance, disappearance and reappearance can be attributed to changing ocean conditions. Standard census counts of 50,100, or 300 specimens could miss rare background occurrences.

Ehrenberg's original brief descriptions and simple drawings are the fountainhead for most silicoflagellate taxonomy. Loeblich et al. (1968) reproduced his original information for the micropaleontologic community. On page 40 they note " $D$. ornamentatum (Ehrenberg, 


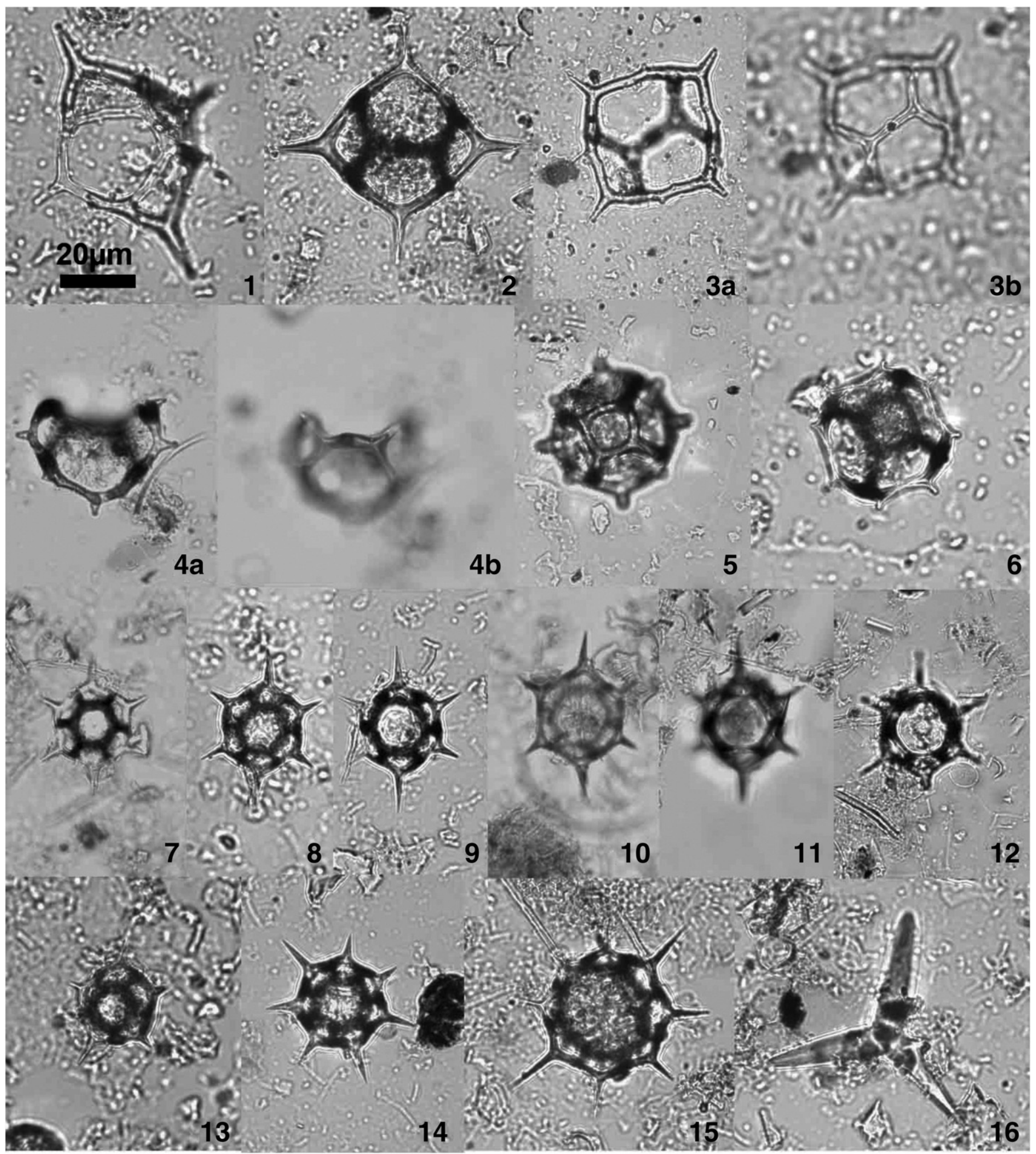

Plate II. Gulf of Alaska silicoflagellates scale bar $=20 \mu \mathrm{m}$. 1. Dictyocha sp. aff. D. stapedia Haeckel, EW0408-85JC, 99-100 cm. 2. Dictyocha sp. aff. D. stapedia Haeckel (large), EW040885JC, 449-450 cm. 3. Dictyocha sp. cf. D. aculeata (Lemmermann) Dumitrica (a, low; b, high focus), EW0408-85JC, 9-10 cm. 4. Dictyocha sp. cf. D. aculeata (Lemmermann) Dumitrica (mimics D. subarctios)(a, low; b, high focus), EW0408-85JC, 99-100 cm. 5. Distephanus octangulatus Wailes, EW0408-85JC, 649-650 cm. 6. Distephanus octangulatus Walies EW040885JC, 649-650 cm. 7. Distephanus speculum speculum (Ehrenberg) Haeckel, EW0408-11JC, 645-647 cm. 8. Distephanus speculum speculum (Ehrenberg) Haeckel, EW0408-11JC, 510$512 \mathrm{~cm}$. 9. Distephanus speculum speculum (Ehrenberg) Haeckel, EW0408-11JC, 510-512 cm. 10. Distephanus speculum speculum (Ehrenberg) Haeckel, EW0408-11JC, 645-647 cm. 11. Distephanus speculum minutus (Bachmann) Bukry, EW0408-11JC, 375-377 cm. 12. Distephanus speculum minutus (Bachmann) Bukry, EW0408-11JC, 510-512 cm. 13. Distephanus quinquangellus Bukry et Foster, EW0408-11JC, 660-662 cm. 14. Distephanus speculum ornamentatum (Ehrenberg) Bukry, n. comb., EW0408-11JC, 1005-1007 cm. 15. Distephanus floridus Bukry, EW0408-11JC, 240-242 cm. 16. Triaxon sponge spicule, EW0408-66JC, 60-62 cm. 
1844), p. 80. Figured by Ehrenberg (1854), pl. 22, Fig. 49." This drawing of a regular polygonal, symmetric 7-spined form is reproduced as their pl.19, Fig. 16. That illustration matches Arctic photographed specimens and our Gulf of Alaska specimens, in regularity and spine, pike and angle proportions (pl II, Fig. 14).

The basionym of Dictyocha septenaria (Ehrenberg, 1844), p. 64, 80. First figured by Ehrenberg (1854), pl. 21, Fig. 45. See Loeblich et al. (1968) reprinted the original figure as pl. 21, Fig. 18. This does not resemble the Arctic specimens, because, unlike $D$. ornamentatum, it has two dominant spines and five short spines, a circular basal ring with no pikes (= supporting spines), and spine arrangement is not symmetric. Also, Locker's (1974) redrawing of the Ehrenberg holotype specimen in the Berlin Museum supports the presence of five very short spines and two dominant spines. His Plate 3, Fig. 1, confirmed the absence of pikes (= supporting spines). Most of the Arctic and North Pacific illustrations show large pikes.

Further, consider Tynan (1957), who reported on the true "Dictyocha speculum Ehrenberg var. septenaria Ehrenberg, Plate I, Fig. 20.” In synonymy, he cited "Distephanus speculum (Ehrenberg) var. septenarius (Ehrenberg), - (Deflandre, 1932), Soc. Franc. Microsc. Bull., vol.1, p. 19, text-fig. 48." He described his specimen from Maryland, thusly "Basal body ring with seven sides of equal length, with seven radial spines of two lengths, one pair long and five individual spines shorter and not paired. Basal accessory spines not conspicuous." This represents usage of the true holotype morphology of $D$. septenaria.

Therefore, the 7-spined forms that are morphologically similar to D. speculum can be classified as: D. speculum ornamentatum (Ehrenberg), n. comb. using the trinomial for biologic classification. But using the correct basionym is the most important consideration.

Distephanus speculum speculum (Ehrenberg) Haeckel (Plate II, Figs. 7-10).

\section{Appendix B. Supplementary data}

Supplementary data associated with this article can be found, in the online version, at doi:10.1016/j.marmicro.2009.04.006.

\section{References}

Addison, J.A., Beget, J.E., Ager, T.A. and Finney, B.P., 2006. Marine evidence of the Latest Pleistocene Mt. Edgecumbe tephra in southeast Alaska, Cordilleran Section GSA meeting, Anchorage, Alaska.

Addison, J.A., Finney, B.P., Dean, W.E., Davies, M.H., 2008. High-resolution records of mid-Holocene paleoceanographic change from the Subarctic Northeast Pacific Ocean. Eos Trans. AGU 89 (53) Fall Meeting Suppl., Abstract PP41B-1458.

Aizawa, C., Oba, T., Okada, H., 2004. Late Quaternary paleoceanography deduced from coccolith assemblages in a piston core recovered off the central Japan coast. Mar. Micropaleontol. 52, 277-297.

Andersen, C., Koç, N., Moros, M., 2004. A highly unstable Holocene climate in the subpolar North Atlantic: evidence from diatoms. Quat. Sci. Rev. 23, 2155-2166.

Anderson, L., Abbott, M.B., Finney, B.P., Burns, S.J., 2005. Regional atmospheric circulation change in the North Pacific during the Holocene inferred from lacustrine carbonate oxygen isotopes, Yukon Territory, Canada. Quat. Res. 64, 21-35.

Andri, E., Gerbaudo, S., Testa, M., 2001. Quaternary siliceous sponge spicules in the western Woodlark Basin, southwest Pacific (ODP Leg 180). Proc. Ocean Drill. Program Sci. Results 180 [Online] <http://www-odp. tamu.edu/publications/ 180_SR/VOLUME/CHAPTERS/153.PDF $>$.

Baldauf, J.G., 1982. Identification of the Holocene-Pleistocene boundary in the Bering Sea by diatoms. Boreas 11, 113-118.

Barron, J.A., Bukry, D., 2007. Development of the California Current during the past 12,000 years based on diatoms and silicoflagellates. Palaeogeogr. Palaeoclimatol. Palaeoecol. 248, 33-338.

Barron, J.A., Heusser, L., Herbert, T., Lyle, M., 2003. High resolution climatic evolution of coastal northern California during the past 16,000 years. Paleoceanography 18 . doi:10.1029/2002PA000768.

Barron, J.A., Bukry, D., Dean, W.A., 2005. Paleoceanographic history of the Guaymas Basin, Gulf of California, during the past 15,000 years based on diatoms, silicoflagellates, and biogenic sediments. Mar. Micropaleontol. 56, 81-102.

Behl, R.J., Kennett, J.P., 1996. Brief Interstadials Events in Santa Barbara Basin, Northeast Pacific, During the Past 60 kyr. Nature 379, 243-246.

Boltovskoy, D., Uliana, E., Wefer, G., 1996. Seasonal variation in the flux of microplankton and radiolarian assemblage compositions in the northeastern tropical Atlantic at 2,195 m. Limnol. Oceanogr. 41, 615-635.
Bond, N.A., Overland, J.E., Spillane, M., Stabeno, P.J., 2003. Recent shifts in the state of the North Pacific. Geophys. Res. Lett. 30 (23), 2183. doi:10.1029/2003GL018597.

Bruland, K.W., 1983. Trace elements in seawater. In: Riley, J.P., Chester, R. (Eds.), Chemical Oceanography, vol. 8. Academic Press, pp. 157-220.

Brumsack, H.J., 1986. The inorganic geochemistry of Cretaceous black shales (DSDP Leg 41 ) in comparison to modern upwelling sediments from the Gulf of California. In: Summerhayes, C.P., Shackleton, N.J. (Eds.), Special Publication - North Atlantic Paleoceanography: Geological Society of London, vol. 21, pp. 447-462.

Bukry, D., 1973. Coccolith and silicoflagellate stratigraphy, Deep Sea Drilling Project, Leg 18, eastern North Pacific. Init. Repts. DSDP, vol. 18, pp. 817-831.

Bukry, D., 1974. Coccoliths as paleosalinity indicators-evidence from Black Sea. Am. Assoc. Pet. Geol. Bull. Mem. 20, 353-363.

Bukry, D., 1975. Coccolith and silicoflagellate stratigraphy, Northwestern Pacific Ocean, Deep Sea Drilling Project Leg 32. Init. Repts., DSDP, vol. 32, pp. 677-701.

Bukry, D., 1976. Cenozoic silicoflagellate and coccolith stratigraphy, South Atlantic Ocean, Deep Sea Drilling Project, Leg 36. Init. Repts. DSDP, vol. 35, pp. 885-917.

Bukry, D., 1978. Cenozoic silicoflagellate and coccolith stratigraphy, northwestern Atlantic Ocean, Deep Sea Drilling Project, Leg 43. Init. Repts. DSDP, vol. 44, pp. 775-805.

Bukry, D., 1980. Silicoflagellate biostratigraphy and paleoecology in the eastern Pacific Ocean, Deep Sea Drilling Project Leg 54. Init. Repts. DSDP, vol. 54, pp. 545-573.

Bukry, D., 1981. Silicoflagellate stratigraphy of offshore California and Baja California Deep Sea Drilling Project Leg 63. Init. Repts. DSDP, vol. 63, pp. 539-557.

Bukry, D., 1985. Mid-Atlantic Ridge coccolith and silicoflagellate biostratigraphy, Deep Sea Drilling Project, Sites 558 and 563: Deep Sea Drilling Project. Init. Repts. DSDP, vol. 82, pp. $591-603$.

Bukry, D., 1986. Miocene silicoflagellates from Chatham Rise, Deep Sea Drilling Project Site 594. Init. Repts. DSDP, vol. 90, pp. 925-937.

Bukry, D., 1987. North Atlantic Quaternary silicoflagellates, Deep Sea Drilling Project Leg 94. Init. Repts. DSDP, vol. 94, pp. 779-783.

Bukry, D., 1995. Silicoflagellates and their geologic applications. U.S. Geological Survey Open-File Report 95-260. 26 pp.

Bukry, D., Foster, J.H., 1973. Silicoflagellate and diatom stratigraphy, Leg 16, Deep Sea Drilling Project. Init. Repts. DSDP, vol. 16, pp. 815-871.

Bukry, D., Monechi, S., 1985. Late Cenozoic silicoflagellates from the northwest Pacific, Deep Sea Drilling Project Leg 86: paleotemperature trends and texture classification. Init. Repts. DSDP, vol. 86, pp. 367-397.

Calkin, P.E., Miles, G.C., Barclay, D.J., 2001. Holocene coastal glaciation of Alaska. Quat. Sci. Rev. 20, 449-461.

Childers, A.R., Whitledge, T.E., Stockwell, D.A., 2005. Seasonal and interannual variability in the distribution of nutrients and chlorophyll a across the Gulf of Alaska shelf: 1998-2000. Deep-sea Res., Part 2, Top. Stud. Oceanogr. 52 (1-2), 193-216.

Clement, A.C., Seager, R., Cane, M.A., 2000. Suppression of El Niño during the midHolocene by changes in the Earth's orbit. Paleoceanography 15, 731-737.

Crusius, J., Calvert, S., Pedersen, T., Sage, D., 1996. Rhenium and molybdenum enrichments in sediments as indicators of oxic, suboxic, and sulfidic conditions of deposition. Earth Planet. Sci. Lett. 145, 65-78.

Dean, W.E., 2007. Sediment geochemical records of productivity and oxygen depletion along the margin of western North America during the past 60,000 years: teleconnections with Greenland Ice and the Cariaco Basin. Quat. Sci. Rev. 26, 98-114

Dean, W.E., Zheng Y, Ortiz J.D., van Geen, A, 2006. Sediment Cd and Mo accumulation in the oxygen-minimum zone of western Baja California linked to global climate over the past 53 kyr. Paleoceanography 22 (PA4209). doi:10.1029/2005PA001239.

Deflandre, G., 1932. Les Silicoflagellés des terres fossils à Diatomées: Soc. Franç Microsc., Bull., vol.1, pp. 10-20.

deVernal, A., Pedersen, T.F., 1997. Micropaleontology and palynology of core PAR87A-10: a 23,000 year record of paleoenvironmental changes in the Gulf of Alaska, northeast North Pacific. Paleoceanography 12, 821-830.

Ehrenberg, C.G. 1844 Mittheilung über 2 neue Lager von Gebirgsmassen aus Infusorien als Meeres-Absatz in Nord-Amerika und eine Vergleichung derselben mit den organischen Kreide-Gebilden in Europa und Afrika Bericht über die zur Bekanntmachung geeigneten Verhandlungen der Königlich-Preussischen Akademie der Wissenschaften zu Berlin, Vol: 1844, 57-97.

Ehrenberg, C.G. 1854 Mikrogeologie. Einundvierzig Tafeln mit über viertausend grossentheils colorirten Figuren, Gezeichnet vom Verfasser. [Atlas]. Leopold Voss, Leipzig., 40 pls.

Emerson, S.R., Huested, S.S., 1991. Ocean anoxia and concentrations of molybdenum and vanadium in seawater. Mar. Chem. 34,177-196.

Engleman, E.E., Jackson, L.L., Norton, D.R., Fischer, A.G., 1985. Determination of carbonate carbon in geological materials by coulometric titration. Chem. Geol. 53, 125-128.

Finney, B.P., Gregory-Eaves, I., Douglas, M.S.V., Smol, J.P., 2002. Fisheries productivity in the northeastern Pacific Ocean over the past 2,200 years. Nature 416, 729-733.

Fisher, D., Dyke, A., Dahl-Jensen, D., Demuth, M., Zdanowicz, C., Bourgeois, J., Koerner, R.M., Mayewski, P., Wake, C., Kreutz, K., Steig, E., Zheng, J., Yalcin, K., Goto-Azuma, K., Luckman, B., Rupper, 2008. The Mt Logan Holocene-late Wisconsin isotope record: tropical Pacific-Yukon connections. Holocene 19 (5), 667-677.

Fryxell, G.R., Hasle, G.R., 1972. Thalassiosira eccentrica (Ehrenb.) Cleve, T. symmetrica sp. nov., and some related centric diatoms. J. Phycol. 8 (4), 297-317.

Fryxell, G.A., Hasle, G.R., 1977. The Genus Thalassiosira: Some species with a modified ring of central strutted processes. In: Simonsen, R. (Ed.), Fourth Symposium on Recent and Fossil Marine Diatoms, pp. 67-98. Beiheft 54 zur Nova Hedwigia.

Grant, W.S., Horner, R.A., 1976. Growth responses to salinity variations in four arctic ice diatoms. J. Phycol. 12, 180-185.

Hasle, G.R., 1978. Some Thalassioisra species with one central process (Bacillariophyceae). Norw. J. Bot. 25, 77-110.

Hasle, G.R., Heimdal, B.R., 1968. Morphology and distribution of the marine centric diatom Thalassiosira antarctica Comber. J. R. Microsc. Soc. 88, 357-369. 
Hay, M.B., Dallimore, A., Thomson, R.E., Calvert, S.E., Pienitz, R., 2007. Siliceous microfossil record of late Holocene oceanography and climate along the west coast of Vancouver Island, British Columbia (Canada). Quat. Res. 67, 33-49.

Hendy, I.L., Kennett, J.P., 2003. Tropical forcing of North Pacific intermediate water distribution during Late Quaternary rapid climate change? Quat. Sci. Rev. 22, 673-689.

Hetherington, R., Reid, R.G.B., 2003. Malacological insights into the marine ecology and changing climate of the late Pleistocene-early Holocene Queen Charlotte Islands archipelago, western Canada, and implications for early peoples. Can. J. Zool. 81, 626-661.

Horner, R., Alexander, V., 1972. Algal populations in Arctic sea ice: an investigation of heterotrophy. Limnol. Oceanogr. 17, 454-458.

Hu, F.S., Kaufman, D., Yoneji, S., Nelson, D., Shemesh, A., Huang, Y., Tian, J., Bond, G., Clegg, B., Brown, T., 2003. Cyclic variation and solar forcing of Holocene climate in the Alaskan subarctic. Science 301 (5641), 1890. doi:10.1126/science.1088568.

Hughen, K.A., Overpeck, J.T., Peterson, L.C., Anderson, R.F., 1996. The nature of varved sedimentation in the Cariaco Basin, Venezuela, and its palaeoclimatic significance. In: Kemp, A.E.S. (Ed.), Palaeoclimatology and Palaeoceanography, from Laminated Sediments: Special Publication - Geological Society London, vol. 116, pp. 171-183.

Hughen, K.A., Overpeck, J.T., Lehman, S.J., Kashgarian, M., Peterson, L.C., Alley, R., 1998 Deglacial ${ }^{14} \mathrm{C}$ calibration, activity and climate from a marine varve record. Nature 391, 65-68.

Ivanochko, T.S., Pedersen, T.F., 2004. Determining the influences of Late Quaternary ventilation and productivity on Santa Barbara Basin sedimentary oxygenation: a multi-proxy approach. Quat. Sci. Rev. 23, 467-480.

Jacobs, L., Emerson, S., Skei, J., 1985. Partitioning and transport of metals across the $\mathrm{O}_{2}$ $\mathrm{H}_{2} \mathrm{~S}$ interface in a permanently anoxic basin, Framvaren Fjord, Norway. Geochim. Cosmochim. Acta 49, 1433-1444.

Katsuki, K., Takahashi, K., 2005. Diatoms as paleoenvironmental proxies for seasona productivity, sea-ice and surface circulation in the Bergin Sea during the late Quaternary. Deep-Sea Res. II 52, 2110-2130.

Kobayashi, H., 1988. Neogene silicoflagellate biostratigraphy of the Japan Sea coastal region, with reference to DSDP Hole 438A. Sci. Rep., Tohoku Univ., 2nd Ser. (Geol.) 59 (1), 1-98

Koutavas, A., Lynch-Stieglitz, J., Marchito Jr., T.M., Sachs, J.P., 2002. El Niño-like pattern in ice age tropical Pacific sea surface temperature. Science 297, 226-230.

Lea, D.W., Pak, D.K., Peterson, L.C., Hughen, K.A., 2003. Synchroneity of tropical and high-latitude Atlantic temperatures over the last glacial termination. Science 301 1361-1364.

Ling, H.-Y., 1970. Silicoflagellates from central North Pacific core sediments. Bull. Am. Paleontol. 58, 85-129.

Ling, H.Y., 1973. Silicoflagellates and ebridians from Leg 19. Initial Reports of the Deep Sea Drilling Project, vol. 19, pp. 751-775.

Ling, H.-Y., 1975. Silicoflagellates and ebridians from Leg 31. Init. Repts. DSDP, vol. 31, pp. $763-777$

Liu, Z., Kutzbach, J., Wu, L., 2000. Modeling climate shift of El Niño variability in the Holocene. Geophys. Res. Lett. 27, 2265-2268.

Locker, S., 1974. Revision der Silicoflagellaten aus der Mikrogeologischen Sammlung von C. G., Ehrenberg. Ecol. Geol. Helv. 67, 631-646.

Locker, S., Martini, E., 1986. Silicoflagellates and some sponge spicules from the southwest Pacific, Deep Sea Drilling Project, Leg 90. Init. Repts. DSDP, vol. 90, pp. 887-924.

Loeblich III, A.R., Loeblich, L.A., Tappan, H., Loeblich Jr., A.R., 1968. Annotated index of fossil and recent silicoflagellates and ebridians with descriptions and illustrations of validly proposed taxa. Mem. Geol. Soc. Amer. 106319 pp.

Lopes, C., Mix, A., Abrantes, F., 2006. Diatoms in northeast Pacific surface sediments as paleoceanographic proxies. Mar. Micropaleontol. 60, 45-65.

Mann, D.H. 1986. Wisconsin and Holocene glaciation of southeast Alaska. In: Hamilton, T.D., Reed, K.M., Thorson, R.M. (Eds.), Glaciation in Alaska: The Geologic Record. InAlaska Geological Society, Anchorage, pp. 237-265.

Mann, D.H., Streveler, G.P., 2008. Post-glacial relative sea level, isostasy, and glacia history in Icy Strait, Southeast Alaska, USA. Quat. Res. 69, 201-216.

Mantua, N.J., Hare, S.R., Zhang, Y., Wallace, J.M., Francis, R.C., 1997. Pacific interdecadal climate oscillation with impacts on salmon production. Bull. Am. Meteorol. Soc. 78, 1069-1079.

Martini, E., 1981. Pliocene and Quaternary diatoms, silicoflagellates, sponge spicules, and endoskeletal dinoflagellates from the Philippine Sea, Deep Sea Drilling Project Legs 59 and 60. Init. Repts. DSDP, vol. 60, pp. 565-574.

Mathewes, R.W., Heusser, L.E., Patterson, R.T., 1993. Evidence of a Younger Dryas-like cooling event on the British Columbia coast. Geology 21, 101-104.

McQuoid, M.R., Hobson, L.A., 2001. A Holocene record of diatom and silicoflagellate microfossils in sediments of Saanich Inlet, ODP Leg 169S. Mar. Geol. 174, 111-123.

Mix, A.C., Lund, D.C., Pisias, N.G., Boden, P., Bornmalm, L., Lyle, M., Pike, J., 1999. Rapid climate oscillations in the Northeast Pacific during the last deglaciation reflect northern and southern hemisphere sources. In: Clark, P.U., Webb, R., Keigwin, L.D. (Eds.), Mechanisms of Global Climate Change at Millennial Time Scales. In: Geophysical Monograph, vol. 112. American Geophysical Union, Washington, DC pp. 127-148.

Moy, C.M., Seltzer, G.O., Rodbell, D.T., Anderson, D.M., 2002. Variability of El Niño Southern Oscillation activity at millennial timescales during the Holocene epoch. Nature 420, 162-165.

Mundy, P.R., Olsson, P., 2005. Chapter 3 Climate and Weather. In: Mundy, P.R. (Ed.) Exxon Valdez Oil Spill Trustee Council. Alaska Sea Grant College Program report AK-
SG-05-01. InUniversity of Alaska Fairbanks, Fairbanks. 214 pp. with 21 figures and 19 tables. ISBN 1-56612-090-X.

Okolodkov, Y.B., 1998. A checklist of dinoflagellates recorded from the Russian Arctic Seas. Sarsia 83, 267-292.

Onodera, J., Takahashi, K., 2005. Silicoflagellate fluxes and environmental variations in the northwestern Pacific during December 1997-May 2000. Deep-Sea Res. II $52,2,218-2,239$.

Ortiz J. O'Connell, S.E., DelViscio, J. Dean, W Carriquiry, J.D., Marchitto, T., Zheng, Y, van Geen, A., 2004. Enhanced marine productivity off western North America during warm climatic intervals of the past $52 \mathrm{ka}$. Geology 32, 521-524.

Parente, A., Cachao, M., Baumann, K.-H., de Abreu, L., Ferreira, J., 2004. Morphometry of Coccolithus pelagicus s. l. (Coccolithophore, Haptophyta) from Portugal, during the last 200 kyr. Micropaleontology 50 (suppl. 1), 107-120.

Patterson, R.T., Guibault, J.-P., Thomson, R.E., Luternauer, J.L., 1995. Foraminiferal evidence of Younger Dryas age cooling on the British Columbia shelf. Géogr. Phys. Quat. 49 (3), 409-428.

Piper, D.Z., 1994. Seawater as the source of minor elements in black shales, phosphorites, and other sedimentary deposits. Chem. Geol. 114, 95-114.

Piper, D.Z., Dean, W.E., 2002. Trace-element deposition in the Cariaco Basin under sulfate reducing conditions-a history of the local hydrography and global climate, $20 \mathrm{ka}$ to the present. U. S. Geol. Surv. Prof. Pap. 167041 pp.

Poelchau, H.S., 1976. Distribution of Holocene silicoflagellates in North Pacific sediments. Micropaleontology 22, 164-193.

Reimer, P.J., et al., 2004. IntCal04 terrestrial radiocarbon age calibration, 0-26 cal kyr BP. Radiocarbon 46 (3), 1029-1058 http://www.radiocarbon.org/IntCal04.htm.

Rodbell, D.T., Seltzer, G.O., Anderson, D.M., Abbott, M.B., Enfield, D.B., Newman, J.H., 1999. An 15,000-year record of El Niño-driven alluviation in southwestern Ecuador. Science 283, 516-520.

Royer, T.C., 2005. Hydrographic responses at a coastal site in the northern Gulf of Alaska to seasonal and interannual forcing. Deep-sea Res., Part 2, Top. Stud. Oceanogr 52 (1-2), 267-288.

Sancetta, C., 1981. Oceanographic and ecologic significance of diatoms in surface sediments of the Bering and Okhotsk seas. Deep-Sea Res. 28, 789-817.

Sancetta, C., 1982. Distribution of diatom species in surface sediments of the Bering and Okhotsk seas. Micropaleontology 28 (3), 221-257.

Sancetta, C., 1992. Comparison of phytoplankton in sediment trap time series and surface sediments along a productivity gradient. Paleoceanography 7, 183-194.

Sancetta, C., Robinson, S.W., 1983. Diatom Evidence on Wisconsin and Holocene events in the Bering Sea. Quat. Res. 20, 232-245.

Sancetta, C., Silvestri, S., 1986. Pliocene-Pleistocene evolution of the North Pacific oceanatmosphere system, interpreted from fossil diatoms. Paleoceanography 1 (2), $163-180$.

Schandelmeier, L., Alexander, V., 1981. An analysis of the influence of ice on spring phytoplankton population structure in the southeast Bering Sea. Limnol. Oceanogr. 26 (5), 935-943.

Schrader, H.-J., Gersonde, R., 1978. Diatoms and silicoflagellates. Utrecht Micropaleontol. Bull. 17, 129-176.

Shiga, K., Koizumi, I., 2000. Latest Quaternary oceanographic changes in the Okhotsk Sea based on diatom records. Mar. Micropaleontol. 38, 91-117.

Snavely Jr., P.D., Bukry, D., Wells, R.E., 1993. Coccolith-bearing late middle Eocene Kerogen Shale, Tillamook Highlands, Northwest Oregon Coast Range. U.S. Geological Survey Open-File Report 93-623.13 pp.

Stabeno, P.J., Bond, N.A., Hermann, A.J., Kachel, N.B., Mordy, C.W., Overland, J.E., 2004. Meteorology and oceanography of the northern Gulf of Alaska. Cont. Shelf Res. 24, 859-897.

Steffensen, J.P., Andersen, K.A., Bigler, M., Clausen, H.B., Dahl-Jensen, D., Fischer, H., GotoAzuma, K., Hansson, M., Johnsen, S.J., Jouzel, J., Masson-Delmotte, V., Popp, T., Rasmussen, S.O., Röthlisberger, R., Ruth, U., Stauffer, B., Siggaard-Andersen, M.-L., Sveinbjörnsdóttir, A.E., Svensson, A., White, J.W.C., 2008. High-resolution Greenland ice core data show abrupt climate change happens in few years. Science 321 (5889), 680. doi:10.1126/science.1157707.

Stuiver, M., Reimer, P.J., 1993. Extended ${ }^{14} \mathrm{C}$ data base and revised CALIB 3.0 radiocarbon age calibration program. Radiocarbon 35 (1), 137-189.

Takahashi, K., 1997. Siliceous microplankton fluxes in the eastern subarctic Pacific, 1982-1986. J. Oceanogr. 53, 455-466.

Takahashi, K., Honjo, S., Tabata, S., 1989. Siliceous phytoplankton flux: interannual variability and response to hydrographic changes in the northeastern Pacific. In: Peterson, D. (Ed.). Aspects of Climate Variability in the Pacific and Western Americas. In: Geophysical Monograph, vol. 55. American Geophysical Union, Washington, DC, pp. 151-160.

Tynan, E.J., 1957. Silicoflagellates of the Calvert Formation (Miocene) of Maryland. Micropaleontology 3 (2), 127-136.

Vabenicka, L., 1999. Braarudosphaera-rich sediments in the Turonian of the Bohemian Cretaceous Basin, Czech Republic. Cretac. Res. 20, 773-782.

von Quillfeldt, C.H. 1996. Ice algae and phytoplankton in north Norwegian and Arctic waters: species composition, succession and distribution. - Ph.D.-dissertation. Norwegian College of Fisheries Science, University of Tromsø: 295 pp.

Zheng Y, van Geen, A. Anderson, R.F., Gardner, J.V., Dean, W.E., 2000. Intensification of the northeast Pacific oxygen minimum zone during the Bölling-Alleröd warm period. Paleoceanography $15,528-536$. 